\title{
Geologic observations in the San Marcos area, Coahuila, Mexico: the case for sediment-hosted stratiform copper-silver mineralization in the Sabinas basin during the Laramide orogeny
}

\author{
Observaciones geológicas en el área de San Marcos, Coahuila, México: el caso de la mineralización \\ estratiforme de cobre-plata en la cuenca de Sabinas durante la orogenia Larámide
}

José Perelló ${ }^{1, *}$

Blaise Cendrars 6736, Vitacura, Santiago, Chile.

* Corresponding author: (J. Perelló) jperello6692@gmail.com
How to cite this article:

Perelló, J., 2021, Geologic observations in the San Marcos area, Coahuila, Mexico: the case for sediment-hosted stratiform copper silver mineralization in the Sabinas basin during the Laramide orogeny: Boletín de la Sociedad Geológica Mexicana, 73 (3), A160321. http://dx.doi.org/10.18268/ BSGM2021v73n3al60321

Manuscript received: January 20, 2021

Corrected manuscript received: March 1, 2021 Manuscript accepted: March 10, 2021

Peer Reviewing under the responsibility of Universidad Nacional Autónoma de México.

This is an open access article under the CC BY-NC-SA license(https://creativecommons.org/licenses/by-nc-sa/4.0/)

\section{ABSTRACT}

The sediment-hosted stratiform copper-silver mineralization in the San Marcos area of Coahuila, northeastern Mexico occurs predominantly at an Early Cretaceous redox boundary between footwall siliciclastic red beds of the San Marcos Formation and hanging-wall carbonate strata of the Cupido Formation in the Sabinas basin. The hypogene mineralization is mainly present as chalcocite-group minerals, with additional bornite and chalcopyrite, and everywhere occurs in both disseminated and vein/veinlet forms. Supergene copper-bearing oxides (malachite, chalcanthite, azurite, chrysocolla) are, however, the dominant surface expression of the mineralization. Additional sediment-hosted stratiform copper-silver mineralization also occurs, albeit erratically, in lower strata of the Sabinas basin as well as in veins in basement granitoids, thus spanning $\sim 3000 \mathrm{~m}$ of basin stratigraphy. Where best developed, the stratiform mineralization displays intense structural control proximal to the regional San Marcos fault system. This major bounding fault, regional in nature and with numerous periods of activity, controlled the evolution of the Sabinas basin. Structural controls on mineralization include stacked, shallow-angle, bedding-parallel, northeast-vergent thrust faults and associated drag folds, in addition to numerous, steeply-dipping, northeast-trending copper-bearing veins and veinlets. The mineralized veins and veinlets, and the bedding-parallel thrusts display mutually crosscutting relationships. These elements are all consistent and in harmony with a regional northeast-trending direction of horizontal shortening accompanying reverse motion of the San Marcos fault system. Inversion along the San Marcos fault system, and the entire Sabinas basin in the Paleogene from $\sim 60$ to $40 \mathrm{Ma}$, resulted from wholesale contractional deformation during the Laramide (Mexican) orogeny. Hence, emplacement of the sediment-hosted stratiform copper-silver mineralization at San Marcos, and elsewhere in the larger Coahuila region, is interpreted as a natural corollary of large-scale, metal-bearing fluid expulsion, migration, and precipitation resulting from orogenic shortening, lithostatic loading, and squeezing of the Sabinas basin during Mexican orogen construction. Although sedimentation of the host strata in the Sabinas basin took place in a pericratonic setting associated with the opening of the Gulf of Mexico, sediment-hosted stratiform copper-silver mineralization occurred during orogenic uplift and conversion of the original basin into an orogen-foreland pair, with similarities to some of the world's largest sediment-hosted stratiform copper provinces.

Keywords: Mexico, Sabinas basin, Laramide orogeny, Mexican orogen, sediment-hosted copper-silver.

\section{RESUMEN}

La mineralización estratiforme de cobre-plata en el área de San Marcos en Coahuila, al noreste de México, se ubica preferentemente en el redox definido por el contacto entre las capas rojas de la Formación San Marcos y las rocas carbonatadas grises de la Formación Cupido, dentro de la cuenca de Sabinas. La mineralización hipogénica de cobre se presenta en forma diseminada y asociada a vetillas y vetas, principalmente como minerales del grupo de la calcosina, además de bornita y calcopirita. Sin embargo, son los productos supergénicos oxidados (malaquita, chalcantita, azurita, crisocola), los que predominan en las exposiciones superficiales. Localmente, la mineralización se encuentra presente en algunos horizontes estratigráficamente inferiores en la secuencia, como también en rocas del basamento granítico, abarcando un espesor de $\sim 3000$ dentro de la cuenca de Sabinas. En aquellas exposiciones con mejor desarrollo, la mineralización estratiforme muestra un fuerte control estructural según su proximidad a la falla San Marcos. Esta estructura, de carácter regional y con numerosos períodos de actividad, efectivamente controló la evolución de la cuenca de Sabinas en la zona en estudio. Los controles estructurales sobre la mineralización incluyen múltiples fallas inversas de bajo ángulo y vergencia al este, apiladas en forma subparalela a la estratificación, además de pliegues de arrastre asociados y corredores de vetas y vetillas mineralizadas sub-verticales y de rumbo predominante al noreste. Las vetas y vetillas mineralizadas y las fallas inversas despliegan, entre ellas, relaciones de contacto de corte mutuo. Estas relaciones son consistentes con un ambiente estructural de acortamiento horizontal dirigido hacia el noreste, como acompañamiento al movimiento inverso de la falla San Marcos. La inversión de la falla San Marcos, y de la cuenca de Sabinas en su totalidad, se produjo en el Paleoceno ( 60-40 Ma), como resultado de la intensa deformación compresiva de la orogénesis Laramídica (o Mexicana). En este sentido, se interpreta el emplazamiento de la mineralización estratiforme de cobre-plata de San Marcos, y en la región de Coahuila en general, como producto de la expulsión. y migración regional de salmueras de la cuenca de Sabinas, en respuesta a procesos de acortamiento orogénico y apilamiento litostático, durante la construcción del orógeno mexicano. Como corolario, se deduce que, si bien la sedimentación en la cuenca de Sabinas tuvo lugar en un ambiente pericratónico promovido por la apertura del Golfo de México, la mineralización estratiforme de cobre-plata que ella hospeda ocurrió durante su inversión y solevantamiento orogénico, coincidentemente con su transformación en cuenca de antepaís. Este ambiente tectónico se compara favorablemente con el de las principales provincias metalogénicas de cobre estratiforme a nivel mundial.

Palabras claves: México, Cuenca de Sabinas, Orogénesis Laramídica, Orógeno Mexicano, mineralización estratiforme de cobre-plata 


\section{Introduction}

Sediment-hosted stratiform copper deposits are tabular, bedding-parallel bodies of zonally-distributed, disseminated and veinlet-controlled copper and copper-iron sulfides located near and at oxidation-reduction boundaries in the host sedimentary sequence (Kirkham, 1989; Brown, 1992; Hitzman et al., 2005). The deposits are important sources of copper, cobalt, and silver and, in the last decade, have accounted for 15 to $\sim 25 \%$ of global copper production, second only to porphyry copper and related deposits (Sillitoe, 2012). The host sedimentary sequences are typically characterized by thick packages of siliciclastic red beds, with additional carbonates and evaporites, deposited in intra and/ or pericratonic basins (Hayes et al., 2015). The largest deposits of the class were formed in basins where large-scale flow of metal-bearing fluid was focused into relatively small rock volumes containing abundant reductants (Hitzman et al., 2010). Less commonly, mineralization can also be hosted by synorogenic terrigenous strata deposited in continental foreland basins (Barton et al., 2018; Perelló et al., 2019).

The timing of mineralization in sediment-hosted stratiform copper deposits relative to host-rock sedimentation has historically remained elusive (e.g., Sillitoe et al., 2017a, 2017b, and references therein), a factor that has complicated the definition of a genetic model for the deposit type and its assignment to specific metallogenic epochs. Multiple syngenetic, diagenetic, and epigenetic models have been outlined over the years (Garlick, 1961; Sales, 1962; Bartholomé et al., 1972; Brown, 1981; Jowett, 1991; Hitzman et al., 2010), including proposals of late diagenetic timing of mineralization, up to 100 m.yr. after active sedimentation of the host strata (Aleinikoff et al., 2012; Milton et al., 2017). Models involving numerous diagenetic and epigenetic mineralization stages spanning protracted basin evolution are currently accepted by some investigators (Selley et al., 2005; Hitzman et al., 2010, 2012; Muchez et al., 2010), whereas others support an overall synorogenic timing of copper introduction (Sillitoe et al., 2017a and references therein; Saintilan et al., 2018; Perelló and Sillitoe, 2018; Perelló et al., 2019, 2021; Twite et al., 2020).

Independent of deposit scale and metallogenic province, copper sulfide-bearing veinlets are common in sediment-hosted copper deposits and are an ubiquitous accompaniment to the stratiform sulfide mineralization (Sillitoe et al., 2010, 2017a, 2017b). Traditionally, however, the veinlets have been considered as products of local remobilization of the disseminated stratiform mineralization and assigned to one or more overprinting late-diagenetic to metamorphic events, with little bearing on primary ore genesis (Brummer, 1955; Garlick, 1961, 1967; Mendelsohn, 1961; Whyte, 1971; Ghandi and Brown, 1975; Hayes and Einaudi, 1986; Price et al., 1988; Richards et al., 1988; Annels, 1989; Sweeney et al., 1991; Cailteux et al.,

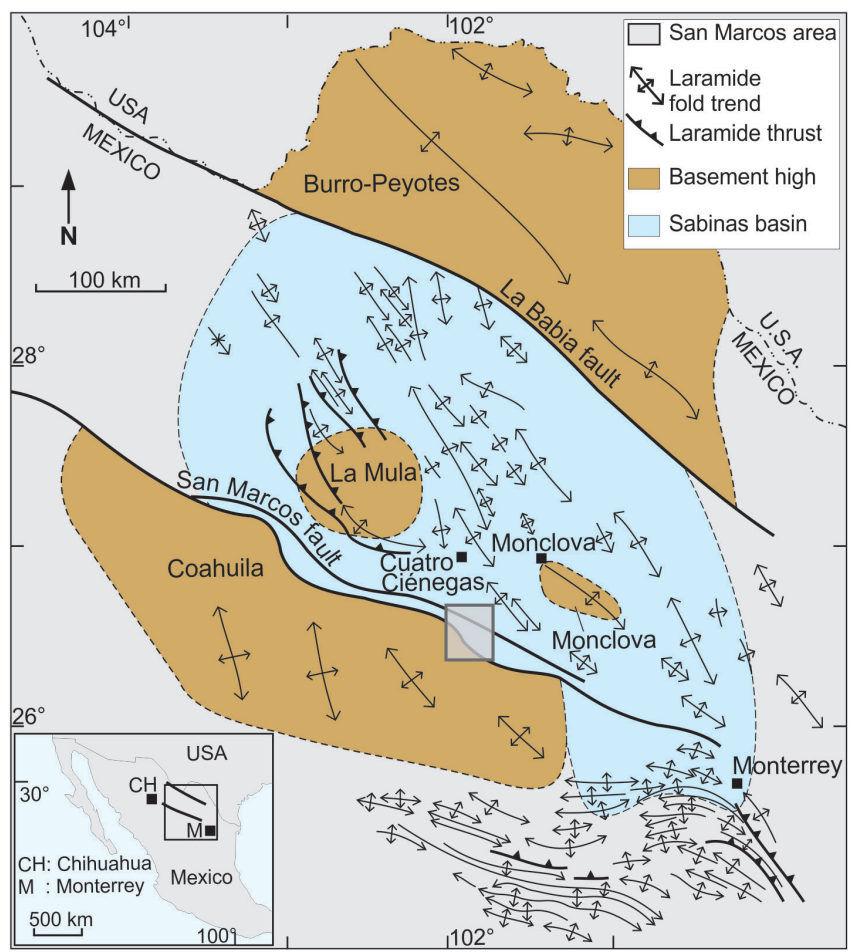

Figure 1 Location of the San Marcos study area in the context of the Sabinas basin, northeastern Mexico. The Sabinas basin is located between two large basement highs (Burro-Peyotes and Coahuila), and comprises the smaller internal blocks (islands) at Monclova and La Mula. The bounding structures of the basin are the regional, northwest-trending San Marcos and La Babia faults. The internal structural fabric corresponds to the fold-and-thrust belt style developed during Laramide shortening. Simplified from Chávez-Cabello (2005). 
2005; Selley et al., 2005; Dewaele et al., 2006; Brems et al., 2009; El Desouky et al., 2009; Huang et al., 2013; Brown, 2017; Oummouch et al., 2017).

This paper briefly describes the geologic setting and salient features of the sediment-hosted copper mineralization in the San Marcos area within Sabinas basin strata exposed in Coahuila, northeastern Mexico (Figure 1). Field observations of sulfide-bearing veinlets accompanying the sediment-hosted stratiform mineralization are described and, in conjunction with available geologic descriptions of the mineralization in the study area, are used as evidence to show that copper introduction was contemporaneous with veinlet emplacement during basin inversion resulting from regional Laramide orogenic processes.

\section{Regional geologic setting and mineralization}

\subsection{THE SABINAS BASIN}

As summarized elsewhere (Padilla y Sánchez, 1986, 2016; Salvador, 1987, 1991; Wilson, 1986; Goldhammer, 1999; Eguiluz de Antuñano, 2001), the Sabinas basin formed part of peninsular Mexico during the Mesozoic opening of the Gulf of Mexico consequent upon dispersion of equatorial western Pangea (e.g., Salvador and Green, 1980; Pindell et al., 2020). Sabinas basin strata, presently exposed in the Sierra Madre Oriental ranges of northeastern Mexico (Figure 1), were deposited on Precambrian and Paleozoic-Triassic basement of predominantly Gondwanan affinities (Dickinson and Lawton, 2001; López et al., 2001; RubioCisneros and Lawton, 2011; Ocampo-Díaz et al., 2014; Centeno-García, 2017; Martini and Ortega-Gutiérrez, 2018). Approximately $6 \mathrm{~km}$ of marine, evaporitic, and fluviatile sedimentary rocks accumulated from the Middle Jurassic to the Paleogene (Eocene), between $\sim 170$ and 40 Ma (e.g., Padilla y Sánchez, 1986; Goldhammer, 1999; Eguiluz de Antuñano, 2001; Pindell et al., 2020), in three principal stages: an initial, rapidly subsiding rift-fill stage (Middle-Late Jurassic), with siliciclastic sedimentary rocks and evaporites; an intermediate stage of platform-dominated facies with carbonate, evaporite, and coastal siliciclastic deposits (Early Cretaceous); and a terminal, regressive stage with terrigenous sedimentation in a foreland setting (Late Cretaceous-Paleogene).
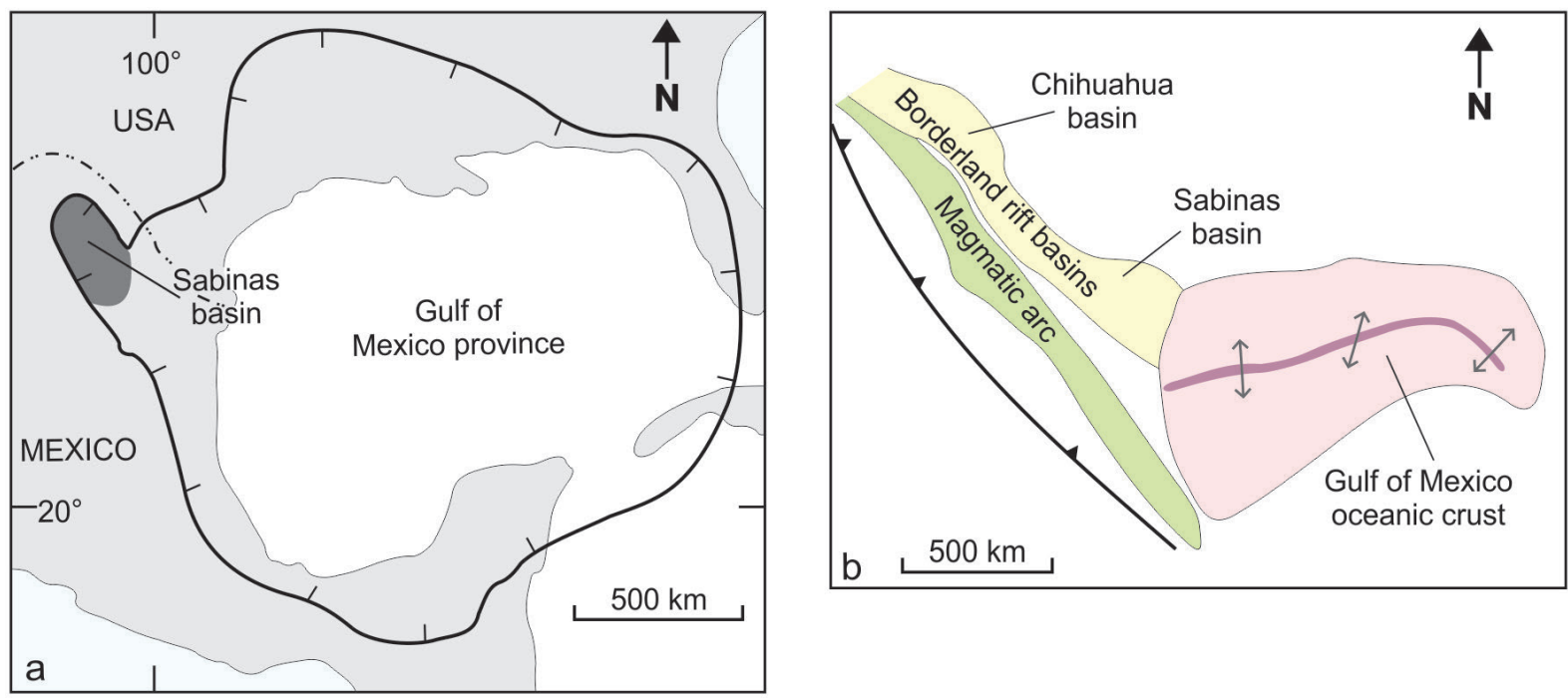

Figure 2 Two generalized interpretations of the setting of the Sabinas basin in the context of the Gulf of Mexico. a). As a northwesttrending pericratonic basin (Salvador, 1991; Eguiluz de Antuñano, 2001). b). As part of a Jurassic, subduction-related border rift system (Stern and Dickinson, 2010). 
Red-bed strata are present in all three stages, although the more voluminous and continuous sequences accumulated during the middle stage in the Late Jurassic (e.g., McKee et al., 1990). Early-stage sedimentation was transgressive over Early Jurassic terrigenous and volcanogenic sequences deposited during initial opening of the Gulf of Mexico (e.g., BarbozaGudiño et al., 1999; Fastovsky et al., 2005; Rubio-Cisneros and Lawton, 2011; Pindell et al., 2020, and references therein), whereas latestage, synorogenic sedimentation in a foreland basin setting accompanied uplift of the Mexican orogen (Fitz-Díaz et al., 2018; Juárez-Arriaga et al., 2019a, 2019b; Davison et al., 2020).

The Sabinas basin has been traditionally assigned to an equatorial, intra- or pericratonic setting as a passive margin embayment accompanying the opening of the Gulf of Mexico, resulting from drifting of North and South America during western Pangea break-up (Salvador, 1987, 1991; Goldhammer, 1999; Pindell and Keenan, 2009; Bird et al., 2005; Marton and Buffler, 2010; Martini and OrtegaGutiérrez, 2018; Pindell et al., 2020; Figure 2a). An alternative interpretation proposes that the Gulf of Mexico originated as a back-arc basin during the Jurassic, and assigns the Sabinas and Chihuahua basins to a series of borderland rift basins along a 2000-km-long magmatic arc associated with subduction of Farallon plate oceanic crust (Stern and Dickinson, 2010; Figure 2b). Irrespective of the geotectonic setting of the basin, Pangea break-up promoted the shuffling of continental blocks, generating an irregular topography in which numerous fault-bounded horsts and grabens controlled the sedimentation patterns within the Sabinas basin as proto-Atlantic sea waters inundated first the Gulf of Mexico and then the adjacent peninsular lands (Padilla y Sánchez, 1986, 2016; Salvador, 1987, 1991; Goldhammer, 1999; Eguiluz de Antuñano, 2001; González-Sánchez et al., 2009; Davison et al., 2020; Pindell et al., 2020). Under these conditions, the northwest-trending Sabinas basin evolved between two large basement highs, the Burro-Peyotes peninsula to the northeast and extensions into the Tamaulipas archipelago and the Coahuila block to the southwest, with additional internal basement blocks at La Mula and Monclova islands (Wilson, 1990; Eguiluz de Antuñano, 2001; Figure 1). Principal bounding structures of the basin included the regional, high-angle San Marcos and La Babia faults, both inferred to have been active during basin sedimentation and later reactivated at the time of basin inversion (Chávez-Cabello, 2005; ChávezCabello et al., 2005, 2007; Bolaños-Rodríguez, 2006; Figures 1 and 3a).

Deformation of the Sabinas basin as well as other basins in the northeast Mexican fold and thrust belt in the Sierra Madre Oriental took place during various stages of continuous and progressive transition from thin- to thick-skinned structural styles, between the Late Cretaceous ( $\sim 90 \mathrm{Ma}$; Turonian) and the middle Eocene ( 40 $\mathrm{Ma}$; Bartonian), in response to a combination of Sevier and Laramide orogenic pulses (Eguiluz de Antuñano et al., 2000; Eguiluz de Antuñano, 2001; Gray and Lawton, 2011; Ramírez-Peña and Chávez-Cabello, 2017; Fitz-Díaz et al., 2018; Williams et al., 2020). Final basin inversion occurred in the middle Eocene ( 50-40 Ma), with folding, thrusting, and high-angle reverse faulting during the regional, relatively low-temperature (100-300 ${ }^{\circ}$; Fitz-Díaz et al., 2011; Fitz-Díaz and van der Pluijm, 2013) shortening of the Laramide orogeny (Eguiluz de Antuñano, 2001; ChávezCabello, 2005; Chávez-Cabello et al., 2005, 2007, 2009; Molina-Garza et al., 2008). Recent literature refers to this wholesale deformation event as the Mexican orogeny (Juárez-Arriaga et al., 2019a; Davison et al., 2020; Gray et al., 2020).

\subsection{SEDIMENT-HOSTED STRATIFORM MINERALIZATION}

Strata within the Sabinas basin and bounding blocks host a variety of mineralization styles genetically related to basin evolution and 
deformation, principally Mississippi Valleytype (MVT) lead-zinc-celestine-barite-fluorite deposits and a currently subeconomic, although metallogenically important group of red bed-type sediment-hosted stratiform copper-silver deposits and prospects (e.g., Tritlla et al., 2006, 2007; González-Sánchez et al., 2009; Camprubí, 2013, 2017; Figure 3b). The copper-silver group defines

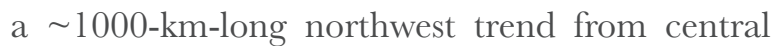
Chihuahua to Tamaulipas (Clark and de la Fuente, 1978; Price et al., 1988; Camprubí, 2013, 2017; García-Alonso et al., 2011; González-Partida et al., 2013, 2017; Figure 3a). The deposits and prospects are hosted by thick (up to $1 \mathrm{~km}$ ) red-bed sequences of Jurassic to Early Cretaceous (Neocomian) age (Figure 3b), with many of them located in the vicinity of regional basement-bounding faults of which the San Marcos area prospects are good examples (Figure 3a).

\section{Sediment-hosted stratiform copper- silver mineralization in the San Marcos area}

\subsection{STRATIGRAPHY AND MINERALIZATION}

The sediment-hosted stratiform mineralization in the San Marcos area (also called Cuatro Ciénegas or Cuatrociénegas; González-Sánchez et al., 2009; García-Alonso et al., 2011), is located approximately $45 \mathrm{~km}$ south of the town of Cuatro Ciénegas in central Coahuila (Figures 1 and 4a) along and near the San Marcos fault, is part of a 250-km-long segment of the main northwest-trending copper-silver belt (Figure 4a). The San Marcos fault constitutes the regional structural contact between the Coahuila block and the Sabinas basin and controlled basin subsidence and sedimentation in the area (McKee et al., 1990;
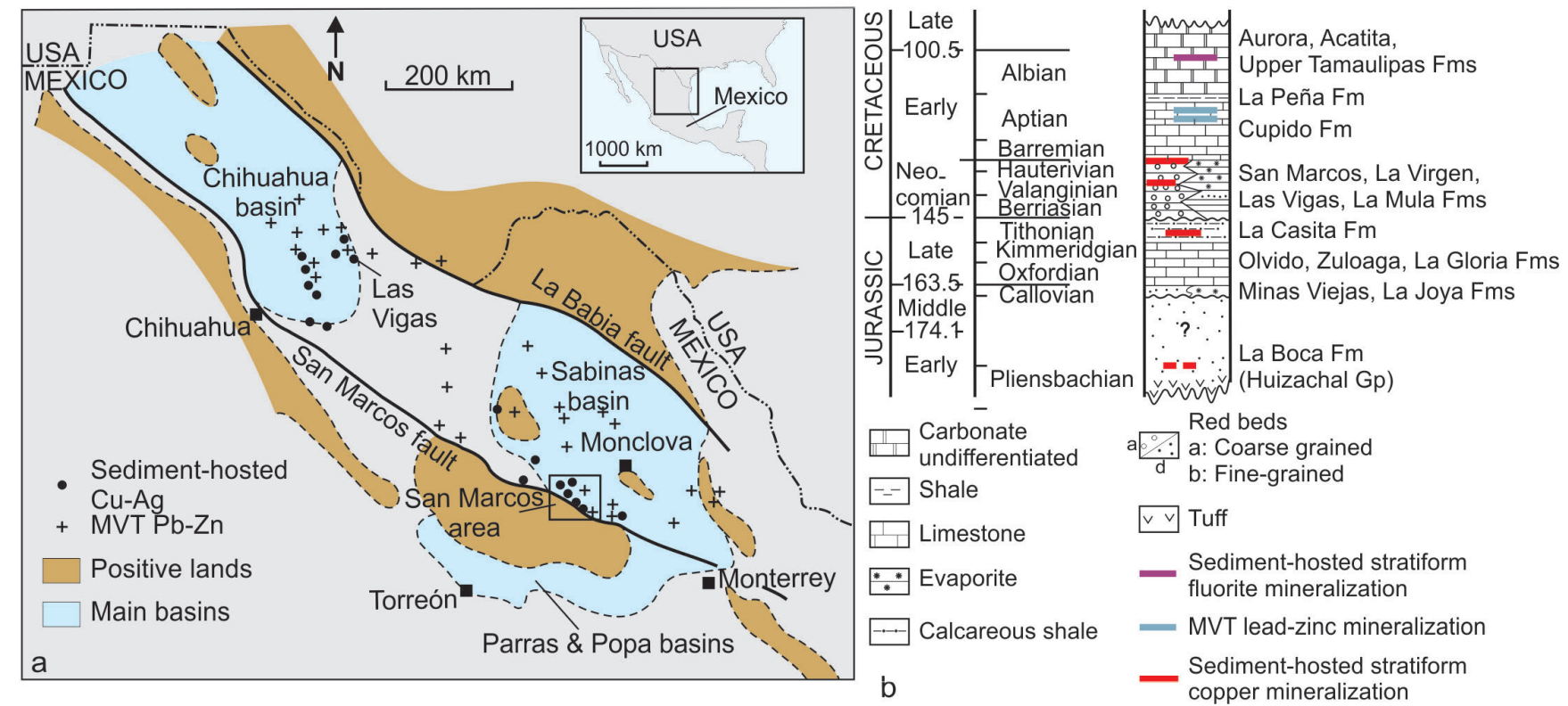

Figure 3 Sediment-hosted stratiform mineralization of various styles and basin stratigraphy of northeastern Mexico. a). Distribution of selected deposits and prospects in the northwesterly-aligned Chihuahua and Sabinas basins. The principal basin-bounding faults of San Marcos and La Babia are highlighted. Adapted from an original compilation by Camprubí (2013, 2017, and references therein). Locations of the study area at San Marcos, southwest of Monclova, and the Las Vigas sediment-hosted copper-silver deposit in the Chihuahua basin, are shown for reference. b). Generalized stratigraphic column of the Sabinas basin and correlative units from the Chihuahua basin. Based on Padilla y Sánchez (1986), McKee et al. (1990), Eguiluz de Antuñano (2001), González-Sánchez et al. (2007, 2009), Rubio-Cisnero and Lawton (2011), and González-Partida et al. (2017). Note the position of the sediment-hosted stratiform copper mineralization in Jurassic and Cretaceous stratigraphy, spanning $>3000 \mathrm{~m}$ of basin fill, and the position, in upper stratigraphy, of the MVT lead-zinc and fluorite mineralization, widespread in northeastern Mexico. 
Chávez-Cabello 2005; Chávez-Cabello et al., 2005, 2007; Figures 1 and 4).

Over $4000 \mathrm{~m}$ of Late Jurassic and Early Cretaceous stratigraphy are exposed in the San Marcos area comprising, from bottom to top, the following principal sequences (McKee et al., 1990; Bolaños-Rodríguez, 2006; Figure 4b): $\sim 2000 \mathrm{~m}$ distributed in three Late Jurassic units of upward-fining siliciclastic rocks, including red beds (Las Palomas, Sierra El Granizo, and Tanque Cuatro Palmas beds, all correlated with the La Casita Formation; Mckee et al., 1990; Eguiluz de Antuñano 2001); 1000 m of Early Cretaceous (Neocomian), coarse-grained siliciclastic red beds (San Marcos Formation); 350-600 m of limestone and shale of late Early Cretaceous (Barremian-Aptian) age (Cupido and La Peña Formations); and $>500 \mathrm{~m}$ of Late Cretaceous (Albian-Ceno- manian and younger) carbonate rocks (Aurora and Acatita Formations and correlative strata; Figure 4b). Basement units comprise low-grade metasiliciclastic rocks of Late Paleozoic age intruded by Permian-Triassic granitoids (McKee et al., 1990; Bolaños-Rodríguez, 2006).

The stratiform disseminated copper-silver mineralization occurs predominantly at or close to an Early Cretaceous redox boundary between footwall siliciclastic red-bed strata of the San Marcos Formation and hanging-wall dolomitic limestone of the Cupido Formation. Scattered mineralized showings within San Marcos sandstone and in Late Jurassic red beds (Sierra El Granizo beds) are also present (e.g., Barbosa-Luna et al., 1998; Ramírez-Gutiérrez and Ramos-Anleu, 2008; Figure 4b), and copper-silver-bearing veins and fractures occur in isolated exposures of basement
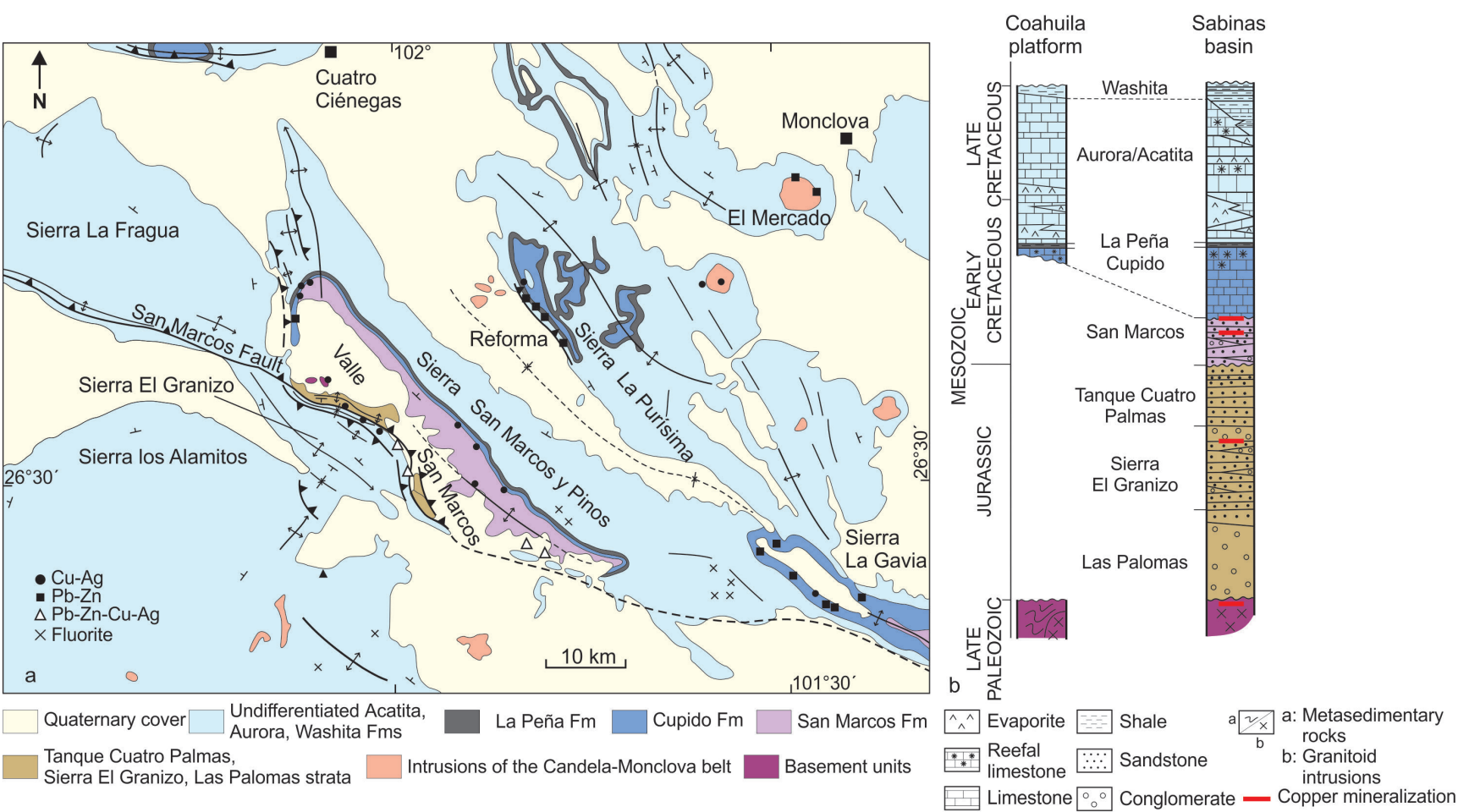

Figure 4 Geologic map and stratigraphy of the larger Monclova-Cuatro Ciénegas region, with emphasis on the San Marcos area (approximate location in Figs. 1 and 3). a). Regional geology, largely simplified from Barbosa-Luna et al. (2008) and González-Ramos et al. (2008). Note the abundance of sediment-hosted stratiform copper-silver and MVT lead-zinc-copper-silver prospects in the San Marcos valley, Sierra La Gavia, and Sierra La Purísima, discussed in the text. Also shown is the mineralization in some intrusions of the CandelaMonclova belt, as at Cerro Mercado. b). Semi detailed stratigraphic column of the Sabinas basin in the study area, with the position of the principal sediment-hosted stratiform copper-silver exposures. Note the mineralization in fissure veins hosted by basement granitoids of the San Marcos area (shown in a). Stratigraphic column simplified after McKee et al. (1990) and Bolaños-Rodríguez (2006). 
granite in the San Marcos valley (Barbosa-Luna, 1998; Barbosa-Luna et al., 1998; Bolaños-Rodríguez, 2006; Figure 4a), thereby spanning a stratigraphic interval of $\sim 3000 \mathrm{~m}$.

Exposures of the sediment-hosted mineralization occur along the foothill slopes of Sierra El Granizo and Sierra San Marcos y Pinos, which together are inferred to form the limbs of a large, composite, northwest-trending antiformal structure (e.g., González-Ramos et al., 1997; Chávez-Cabello, 2005; Figures 4 and 5). The southwestern limb of this antiform at Sierra El Granizo runs along the San Marcos fault and is intensely disrupted by east-vergent thrust faults and associated
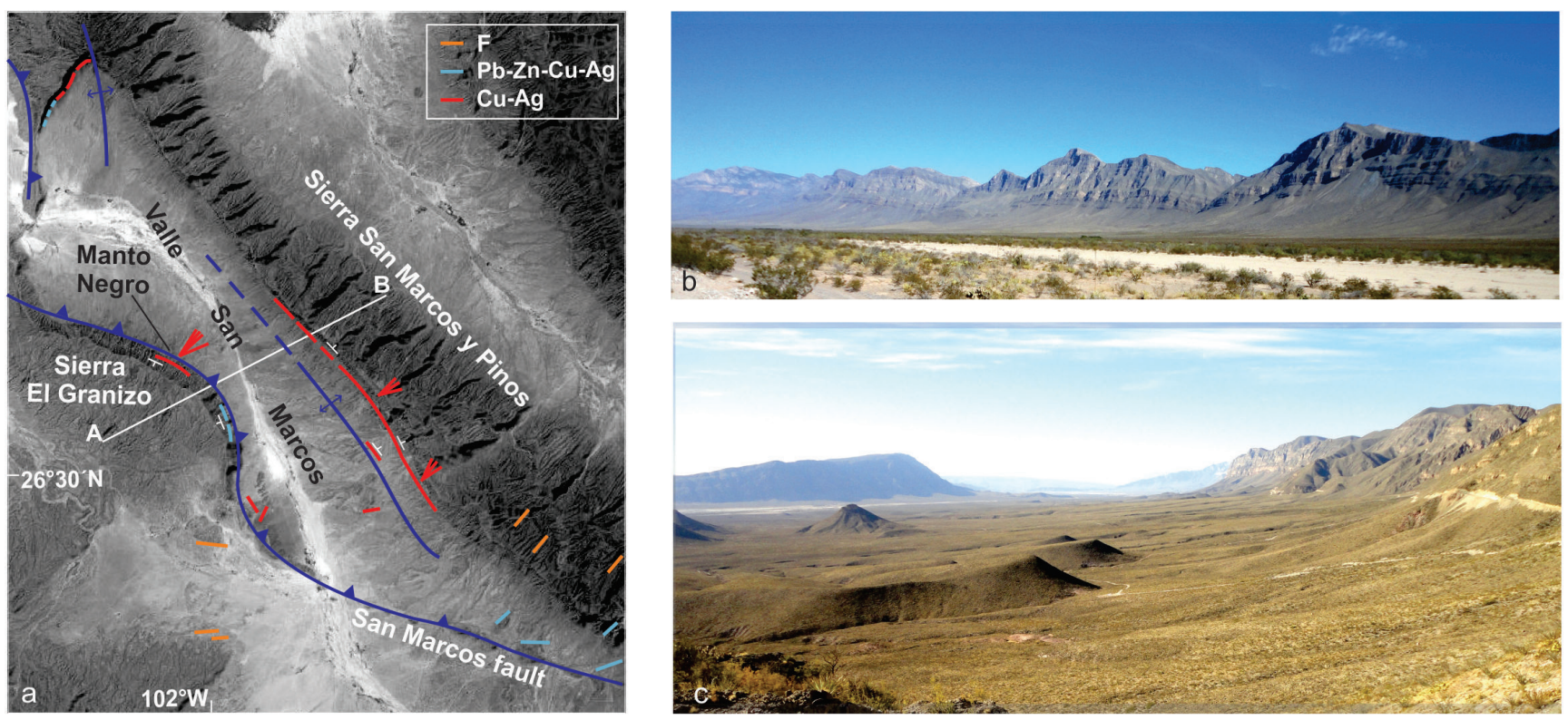

A

B

Sierra

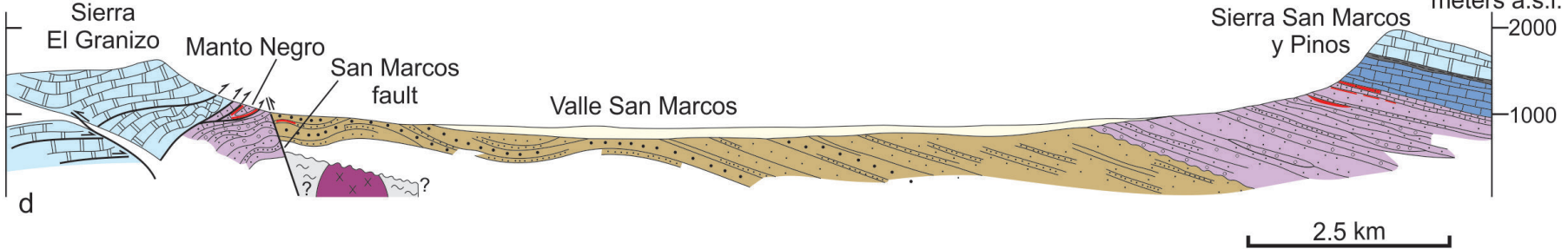

$\llbracket$ Undifferentiated Aurora, Acatita Fms $\amalg$ La Peña Fm $\amalg$ Cupido Fm

San Marcos Fm $\quad \ldots$ Tanque Cuatro Palma, El Granizo, Las Palomas strata $a \underset{\mathrm{b}}{\mathrm{a}} \mathrm{b}$ : Granitoid intrusions

$\rightleftarrows$ Sediment-hosted stratiform copper-silver mineralization

Figure 5 Aspects of the geology and mineralization in the San Marcos area. a). Digital terrane image of the San Marcos area showing principal structural and mineralization elements. The long red line shows the distribution of the sediment-hosted stratiform coppersilver mineralization, with important continuity along Sierra San Marcos y Pinos. Short red lines mark the location of additional single showings. The strike and dip symbols display the attitude of the stratiform mineralization. The red rosettes indicate the principal trends of the studied mineralized veins and veinlets. The other symbols in the legend correspond to large mineralized veins, as described in the literature, with corresponding strikes. See text for discussion. Manto Negro is shown for reference. Based on data collected during this work and references cited in the text. $b$-c). Field views of the Sierra San Marcos y Pino and San Marcos valley. $d$ ). Simplified, schematic geologic section (location shown in a) of the San Marcos area. Note the structural complications of the strata in the Sierra El Granizo foothills, with multiple shallow-angle, bedding-parallel thrusts and associated folds. The subvertical attitude of the San Marcos fault is also highlighted as well as the location of the sediment-hosted stratiform copper-silver mineralization at Sierra El Granizo and Sierra San Marcos y Pinos. Based on structural and stratigraphic data from McKee et al. (1990), Chávez-Cabello (2005), and Bolaños-Rodríguez (2006). 
folds (McKee et al., 1990; Chávez-Cabello, 2005; Chávez-Cabello et al., 2005, 2007; Bolaños-Rodríguez, 2006; Alonso-Manuel et al., 2020), whereas the exposures along the Sierra San Marcos y Pinos are relatively continuous over several kilometers along bedding (Figures 4 and 5). The principal single mineral occurrence is Manto Negro (also known as Manto Rojo; Barbosa-Luna, 1998) at Sierra El Granizo, with an estimated artisanal production of $100 \mathrm{t}$ of concentrate containing $70-75 \% \mathrm{Cu}$ from ore with head grades of $\sim 2$ to 3\% Cu (Rivera-Martínez, 1993). Silver contents of $\sim 40-50 \mathrm{ppm}$ reported for Manto Negro and neighboring showings (Rivera-Martínez, 1993) are within the upper range of silver values for numerous prospects from the larger Monclova region (10-70 ppm; González-Ramos et al., 1997; Barbosa-Luna, 1998; Barbosa-Luna et al., 1998; Santiago-Carrasco, 1998; Ramírez-Gutiérrez and Ramos-Anleu, 2008), and underscore the coppersilver signature of the sediment-hosted stratiform mineralization regionally (García-Alonso et al., 2011; Camprubí, 2013, 2017; González-Partida et al., 2017). The copper mineralization predominantly occurs as supergene carbonates, sulfates, silicates, and oxides (malachite, azurite, chalcanthite, chrysocolla, cuprite, and manganese wads), but hypogene copper-bearing sulfides, including chalcocite-group minerals (chalcocite, digenite, djurleite), bornite, and chalcopyrite, have also been reported (Rivera-Martínez, 1993; González-Ramos et al., 1997; Barbosa-Luna, 1998; Santiago-Carrasco, 1998; Ramírez-Gutiérrez and Ramos-Anleu, 2008). The host for silver in the copper mineralization is unknown, but it is likely to be in solid solution with the copper-bearing sulfides, mainly chalcocite and bornite, as documented in sediment-hosted copper-silver deposits elsewhere (e.g., Kelepile et al., 2020).

\subsection{MINERALIZATION STYLES}

On both limbs of the large San Marcos anticline, the studied stratiform copper-silver mineralization occurs within a stratigraphic interval comprising carbonaceous siltstone, micritic limestone, and arkosic sandstone, which marks the transitional contact between coarse-grained, poorly-sorted, red-bed siliciclastic footwall strata of the San Marcos Formation and hanging-wall carbonate rocks of the Cupido Formation (Figures $4 \mathrm{~b}$ and 6). In the Sierra San Marcos y Pinos, the copper-bearing interval averages $\sim 1.5 \mathrm{~m}$ thick, with mineralization occurring as disseminations and fractures along gently northeast-dipping, thinly bedded, illite-stable, dark-gray to black, carbonaceous siltstone, silty sandstone, and calcareous shale interbedded with thickly- and locally cross-bedded, greenish sandstone and fine-grained conglomerate (Figures 6a, 6b, 6e, $6 \mathrm{f}$ and $6 \mathrm{~g}$ ). In the foothills of Sierra El Granizo, the $\sim 4$ - to 6-m-thick, southwest-dipping mineralized section is contained in an identical, although highly distorted package of alternating greenish sandstone and dark gray to black pyritic siltstone, within a structural wedge of San Marcos Formation strata located between undifferentiated carbonate rocks of the Cupido and Aurora Formations in the hanging wall and reddish siliciclastic rocks of the Sierra El Granizo beds in the footwall (e.g., McKee et al., 1990; García-Alonso et al., 2011; Figures 5d and 6c). Although the majority of the sediment-hosted stratiform copper-silver mineralization in the San Marcos area is confined to the carbonaceous strata, arkosic sandstone and conglomerate are also mineralized at Sierra San Marcos y Pinos (e.g., García-Alonso et al., 2011; Figures 6e and 6f). Locally, along the San Marcos valley, discrete stratigraphic horizons of the San Marcos redbed sequence contain copper mineralization in decimeter- to meter-thick bleached conglomerate and sandstone lenses in which fossilized wood fragments have been partially replaced by copper-bearing minerals (Figures 6d and 6h), identical to sediment-hosted stratiform copper-silver mineralization elsewhere in the region (e.g., Las Vigas, Chihuahua; González-Partida et al., 2017). Also, at San Marcos, the inherent primary porosity of certain conglomerate lenses next to localized redox boundaries in otherwise fine-grained strata, appears to have aided fluid flow and sulfide precipitation (Figure 6f). 

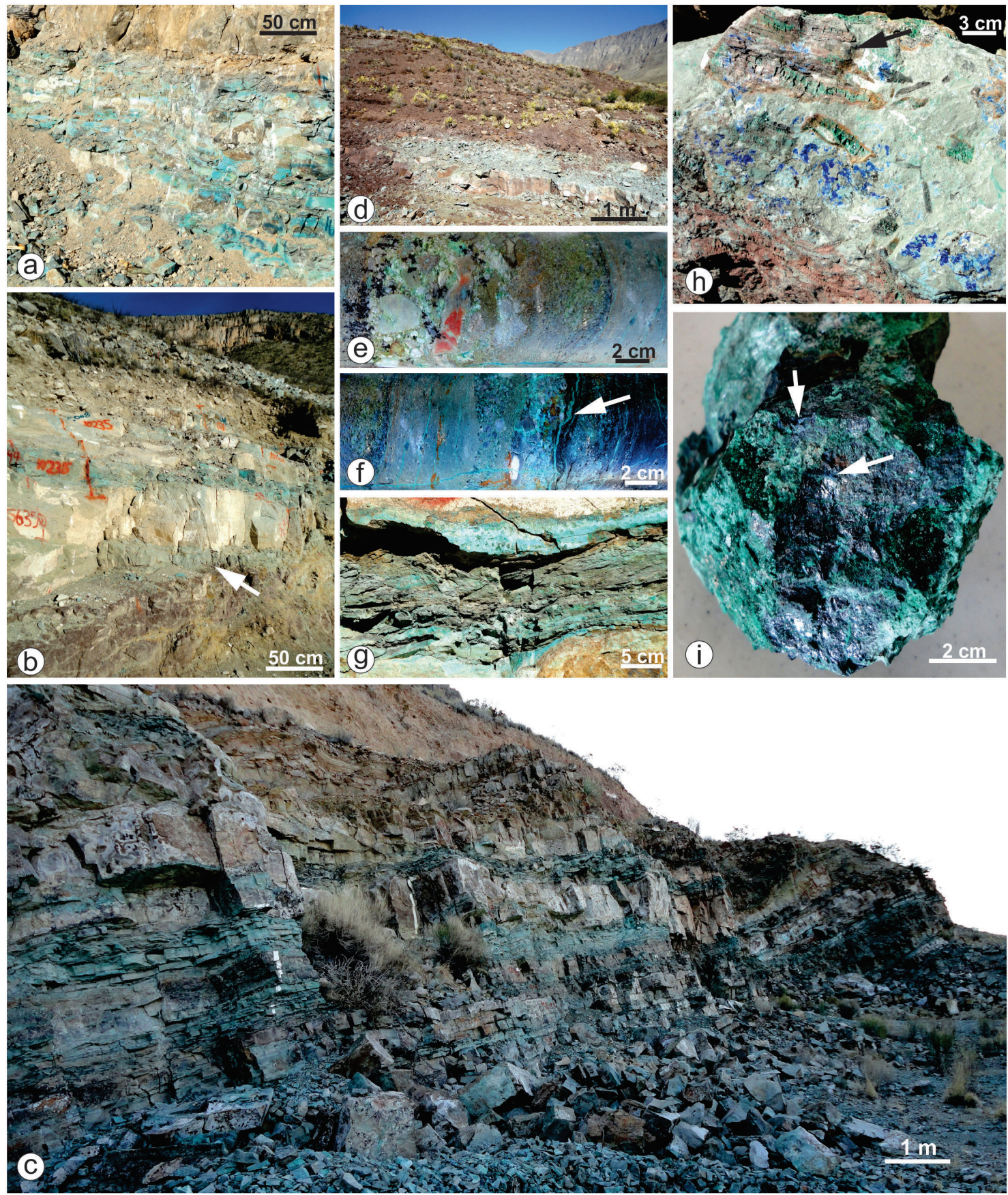

Figure 6 Aspects of the sediment-hosted stratiform mineralization in the San Marcos area. $a-b$ ). Views of the stratiform mineralization at Sierra San Marcos y Pinos. The redox interface in $b$ is marked by the arrow, with the mineralized interval located right above it. c). View of the exposed mineralization in the Manto Negro area. d). View of a bleached, lens-like mineralized horizon within redbed siliciclastic strata of the San Marcos Formation. $e-f$ ). Close-up views highlighting various favorable strata for mineralization: conglomerate in $e$ and the contact between bleached sandstone and black carbonaceous shale in $f$ (marked by an arrow). $g$ ). Close-up view of a carbonaceous shale interbedded with bleached sandstone. In this case, the mineralization is closely related to the shale unit, in contrast to the style shown in Figure $f$, above. $h$ ). Close-up view of a sample collected from the outcrop shown in Figure $d$, in which fossilized plants and wood fragments are partially replaced by malachite and azurite. The arrow highlights a wood fragment. $i$ ). Close-up view of a massive hypogene chalcocite vein with localized remnants of bornite, shown by arrows. These bornite cores imply a paragenetic growth sequence from bornite to chalcocite, typical of sediment-hosted stratiform copper deposits. The green rimming material is malachite, representing the in-situ supergene oxidation of chalcocite. 
The bulk of the exposed copper mineralization in the San Marcos area comprises various supergene copper-bearing oxidation products (malachite, azurite, chrysocolla, copper pitch, neotocite, pitch limonite, and undifferentiated copper wads; Figures 6 and 7), although hypogene copper-bearing sulfides can be found in shallow workings and as relict grains in polished slabs. Chalcocite, as a general field term for chalcocite-group minerals, is the principal sulfide species observed (Figures $6 \mathrm{i}$ and $7 \mathrm{c}, 7 \mathrm{~d}, 7 \mathrm{e}, 7 \mathrm{k}$ ), and the presence of localized cores of bornite assists in definition of a typical paragenetic sequence from early bornite to later chalcocite (Figure 6i). Djurleite, digenite, and chalcopyrite have also been described from exposures in the area (Barbosa-Luna, 1998; Santiago-Carrasco, 1998). Fine-grained chalcocite disseminations occur as arborescent replacements of minute, framboidal, diagenetic pyrite grains in the stratiform disseminated mineralization (e.g., García-Alonso et al., 2011), whereas coarsegrained chalcocite is characteristic of massive, centimeter-wide, chalcocite-only veins or together with bornite, as well as veins and veinlets with various proportions of quartz, calcite, and barite (Figures $6 \mathrm{i}$ and $7 \mathrm{c}, 7 \mathrm{~d}, 7 \mathrm{e}$ ). Laterally distanced from the chalcocite-dominant zones along certain exposures in the Sierra de San Marcos y Pinos, veinlets and disseminations of pitch limonite, neotocite, and chrysocolla are present: an association considered to represent the in-situ oxidative weathering products of low-pyrite, chalcopyrite-bearing hypogene mineralization (e.g., Buckley and Woods, 1984; Sillitoe, 2005; Figures 7a and 7b). These assemblages suggest that a lateral zonation, from central chalcocite-bornite to peripheral chalcopyrite, is present at San Marcos, although detailed mapping would be required to confirm this.

\subsection{VEINS, VEINLETS, STRUCTURE, AND STRATIFORM COPPER-SILVER MINERALIZATION}

Various types of mineralized veins and veinlets are associated with the sediment-hosted stratiform copper-silver mineralization in the San Marcos area. The majority comprises vertical to subvertical $\left(80-90^{\circ}\right)$, planar veins with well-defined margins and a characteristic syntaxial, blocky fill of one or more of quartz, calcite, barite, and copper-bearing sulfides and/or their derivative oxidation products. They can occur singly and approximate $1 \mathrm{~cm}$ wide or multiply along subparallel arrays, which locally coalesce to form zones from 1 to several meters wide (Figures $7 f$ and 7h). Sigmoidal and bedding-parallel veinlets also occur locally, where deformation of the host rock is more intense (Figure 7j). Although the paucity of exposure inhibited measurement of statistically meaningful populations during the present study, single and composite vein/veinlet swarms typically strike from $\mathrm{N} 35^{\circ} \mathrm{E}$ to $\mathrm{N} 60^{\circ} \mathrm{E}$ (Figure $5 \mathrm{a}$ ), which are parallel to the dominant extensional joint orientations, and typically run nearly perpendicular to the strike of the rotated host stratigraphy (Figure 7). The veins and veinlets characteristically display sharp walls and lack brecciation and gouge zones, although slickensides along vein margins are very locally developed and indicative of strike-slip motion, but with minimal vertical offset of the host rocks. Dilation is apparent in most veins and veinlets, hence the characteristic syntaxial, blocky, and massive fill. These features, as well as the overall lack of fault plane indicators in the wall rocks, suggest that they originated as predominantly opening mode fractures, with opening concordant with northwest-southeast extension ( $\sigma 3)$. Locally, tree-like arrays occur (Figure 8h), whereby discrete thin veins, veinlets, and fractures propagate vertically and merge into a single, wider, and bigger vein, like the roots of a tree, reflecting the upward ascent of overpressured fluid along planes of weakness (e.g., Bons et al., 2012). Elsewhere in the larger San Marcos area, larger copper-bearing vein systems, typically tens to hundreds of meters in strike length, display similar northeast-trending attitudes and opening modes (e.g., Ramírez-Gutiérrez and Ramos-Anleu, 2008; Figure 5a). It is noteworthy that everywhere in the San Marcos and nearby areas, veins, veinlets, and disseminated stratiform mineralization possess the same 

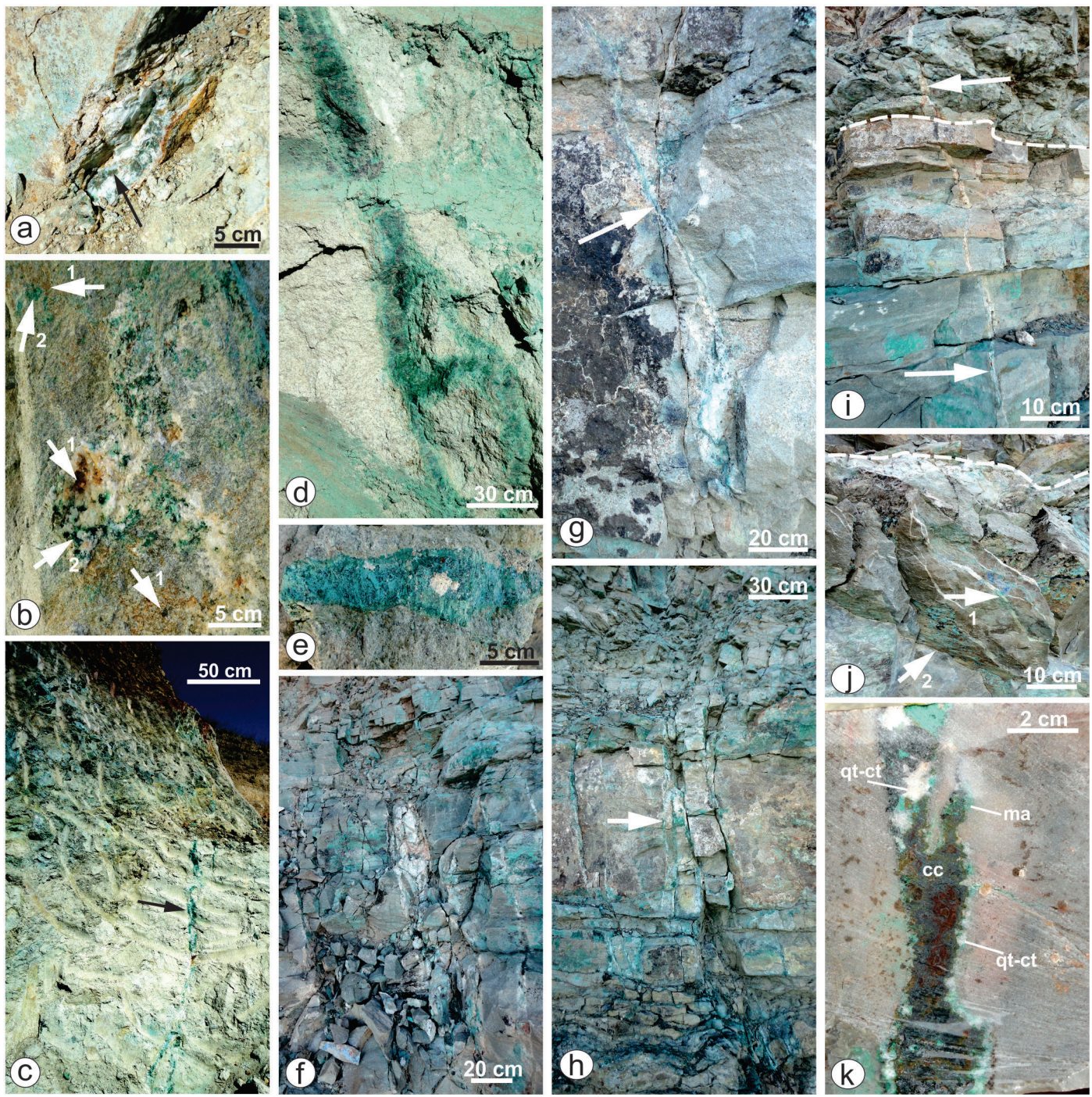

Figure 7 Aspects of the vein- and veinlet-controlled mineralization in the San Marcos area. a). A quartz-calcite-barite vein showing coarsegrained clots of pitch limonite (highlighted by arrow) and green, copper-bearing oxides. Note that the same assemblage occurs as disseminations in the adjacent bleached sandstone. $b$ ). Close-up view of the internal fill of another veinlet from Sierra San Marcos y Pinos. The veinlet shows the classic blocky fill of quartz and calcite, with additional coarse-grained clots of pitch limonite and green copper-bearing oxides (shown by arrows 1 and 2, respectively). The decolored host sandstone comprises the same copper-bearing assemblages, as highlighted by arrows 1 and 2, respectively. c). View of a vertical, massive chalcocite vein from Sierra San Marcos y Pinos. The massive chalcocite vein is highlighted by the arrow, and it is transgressive to thickly-bedded, bleached sandstone. Note the stratiform mineralization immediately above the vein. d). Another partially oxidized chalcocite vein from Sierra San Marcos y Pinos crosscutting bleached sandstone. $e$ ). Close-up view of a piece of the vein portrayed in Figure $d$, highlighting the massive nature of the chalcocite. $f$ ). View of a vertical, quartz-calcite swarm of veinlets which locally coalesce to form a wider and more massive vein. The veins and veinlets cut the rotated beds of uppermost San Marcos Formation in the Manto Negro area (Figure 5a). Most single veinlets carry coarse-grained spots of copper oxides, identical to those that form the disseminated mineralization in the host strata. g). A close-up view of another veinlet (marked by the arrow) in the Manto Negro area, transgressing bleached sandstone. h). Another swarm-like array of vertical, copper-bearing veinlets from the Manto Negro area (shown by arrow). These veinlets transgress massive solid sandstone in the central portion of the photograph, and highly broken and sheared shale in the footwall portion. The foliated texture of the footwall shale is characteristic of the low-angle, bedding-parallel thrust faults of the Sierra El Granizo area (see text for descriptions). Note that the veinlets are truncated and fragmented by another thrust in the hanging-wall part of the section, implying that veinlet emplacement and thrusting took place broadly synchronously. i). Another view to further highlight the temporal relationship between thrusting and mineralization at Manto Negro. In this case, the mineralized veinlet cuts both the massive sandstone and the blocky, sheared shale on top (contact highlighted by segmented line). Note the scaly fabric developed in the shale, as part of a low-angle, bedding-parallel thrust. $J$ ). View of a series of sigmoidal (S-type), mineralized veinlets (shown by arrow 1 ) in a sandstone block involved in a thrust fault. The thrust slip surface is shown by a segmented line above the block. Note the horizontal, mineralized slickensides developed on this block (marked by arrow 2). k). Close-up view of a quartz-calcite-chalcocite veinlet, highlighting the blocky texture of the quartz and calcite fill and the internal massive nature of the chalcocite. Chalcocite is replaced by a dark, lustrous, limonitic mineral admixture (almagre). Abbreviations: alm: almagre; cc: chalcocite; ct: calcite; ma: malachite; qt: quartz. 
copper-bearing species and assemblages, a feature that in sediment-hosted stratiform copper deposits elsewhere has been considered to demonstrate the contemporaneity of both the vein-controlled and disseminated stratiform mineralization (e.g., Sillitoe et al., 2010, 2017a, 2017b, and references therein).

In general, veining intensity at San Marcos is proportional to the intensity of deformation affecting the host sequence: an empirical observation that attests to a close relationship between geologic structure and sediment-hosted stratiform mineralization. For example, at Manto Negro (Figures 4 and 5), stratiform copper mineralization is hosted by zones of low-angle, bedding-parallel thrust faults predominantly accommodated by fine-grained silty and carbonaceous horizons interbedded with more rigid sandstone and conglomerate of the San Marcos Formation (Figure 8). The thrust faults are characterized by scaly fabrics involving polished anastomosing surfaces, phacoidal forms, sheared competent blocks and concretions, and injected and foliated shale bands, typical of thrusts elsewhere (e.g., Vannucchi et al., 2003; Morley et al., 2017; Vannucchi, 2019; Figures 8a, 8b, 8c, 8e, 8g). Tectonic thickening of the host mineralized sequence is apparent: 4 to $6 \mathrm{~m}$ in comparison to $1-2 \mathrm{~m}$ in less deformed sections in the San Marcos area. Associated chevron folds in structurally overlying strata, as well as sigmoidal (S-type), copper-bearing quartz-calcite veinlets within deformed strata define an overall northeast-directed shortening and subhorizontal direction of transport (Figure 8d), congruent with the structural observations and interpretations of Chávez-Cabello (2005) for areas nearby. Moreover, the copper-bearing quartz-calcite veins and veinlets display mutually crosscutting relationships with the thrust faults: while some single veinlets and swarms are truncated and fragmented by the faults other sets of similar mineralogy transect almost perpendicularly both host stratigraphy, thrust slip planes, and fault zones (Figures $7 \mathrm{~h}$ and 7i), thereby implying contemporaneity of deformation and veining events (e.g., Engelder, 1985; Laubach and Ward, 2006; Fitz-Díaz et al., 2011;
Williams et al., 2020). Similarly, along Sierra San Marcos y Pinos, stratiform copper mineralization is also hosted locally by shallow-angle, bedding-parallel, northeast-vergent slip surfaces characterized by concretional structures and centimetric zones of cleaved shale tectonically injected into more competent host sandstone (Figure 8g).

\subsection{STRATIFORM LEAD-ZING-SILVER MINERALIZATION}

Numerous sediment-hosted stratiform prospects in the larger Monclova region display the conventional zoning from centrally located copper-silver to peripheral lead-zinc-silver mineralization. The prospects and old workings at Mineral Refoma in Sierra La Purísima and those along Sierra La Gavia (Figure 4a) are classic examples of this metal zonation (González-Ramos et al., 1997; Santiago-Carrasco, 1998), but many others are also present at San Marcos, where the disseminated stratiform mineralization is spatially associated with veins containing various proportions of lead, zinc, copper, and silver (Barbosa-Luna, 1998; Ramírez-Gutiérrez and Ramos-Anleu, 2008).

The majority of the stratiform lead-zinc-silver prospects are hosted by dolomitic limestone of the Cupido Formation, typically located tens to hundreds of meters stratigraphically above and laterally to the copper-bearing siliciclastic strata of the San Marcos Formation (Figures 3b and 4c). Sphalerite and galena, accompanied by various proportions of quartz, barite, and calcite, occur as disseminations, fracture fillings, veins, chimney-like breccias, and karst cavity fillings, and a comparison with the MVT mineralization style has long been established (Barbosa-Luna, 1998; Tritlla et al., 2006, 2007; González-Partida et al., 2007, 2009, 2013; Camprubí, 2017). However, in other cases, the lead-zinc mineralization is disseminated and stratiform, and the transition from copper to leadzinc takes place within single horizons or across thin stratigraphic intervals in the uppermost part of the San Marcos Formation, or immediately at the contact with hanging-wall strata of the Cupido Formation (González-Ramos et al., 1997). 

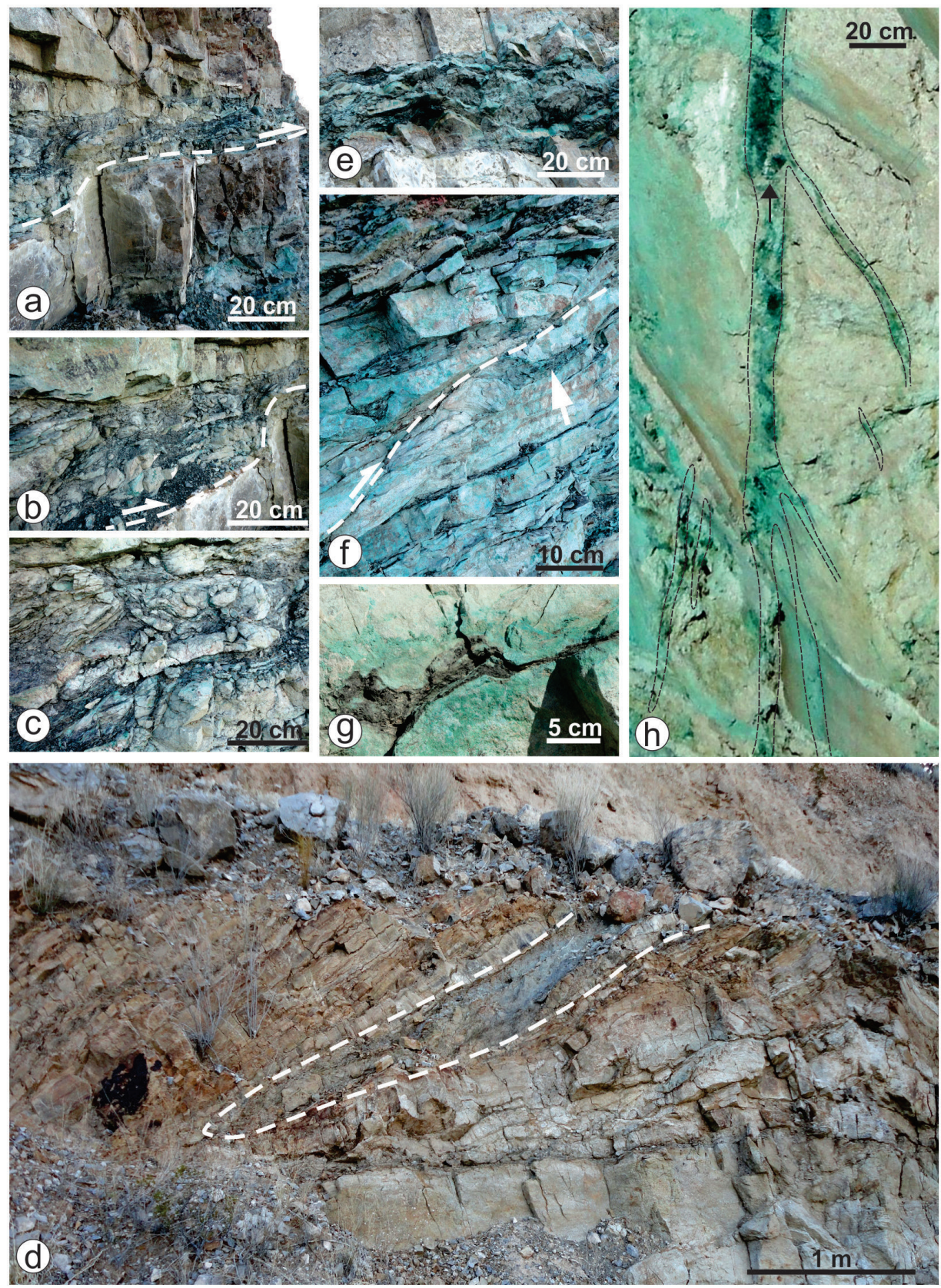

Figure 8 Detailed aspects of the structural controls on mineralization in the San Marcos area. $a-c)$. Various views of a mineralized thrust at Manto Negro, with deformation accommodated by black shale atop massive, bleached sandstone. The thrust slip surface is marked by a segmented line in $a$, whereas $b$ and $c$ are close-up views highlighting the scaly fabric developed in the thrust zone. Note the anastomosing surfaces, phacoidal forms, sheared competent blocks and concretions, and irregularly foliated shale bands. $d$ ). View of a chevron-type fold developed at the expense of a thinly-bedded carbonate sequence (Cupido Formation) located immediate above the mineralized section at Manto Negro. $e$ ). View of another mineralized thrust fault affecting carbonaceous shale. Note the irregular forms of the sheared competent blocks of shale in a finer-grained matrix composed of broken, phacoidal pieces, and semi-foliated shale. $f$ ). Close-up view of a small-scale, reverse slip surface in thinly bedded mineralized sandstone (marked by the segmented line). A seam of injected shale accommodates to the slip surface and is partially offset by it. g). Close-up view of a foliated shale seam tectonically injected into massive and thickly bedded sandstone along Sierra San Marcos y Pinos. Note the distribution of the copper-bearing oxide mineralization. h). View of a partially oxidized massive chalcocite vein from Sierra San Marcos y Pinos. Note the vertical attitude of the principal vein and the array of secondary veins that merge into it, like the roots of a tree, suggestive of the upward ascend of overpressured fluid along planes of weakness. See text for discussion. 


\section{Discussion}

\subsection{TIMING OF SEDIMENT-HOSTED STRATIFORM COPPER MINERALIZATION IN THE SAN MARCOS AREA}

The predominant northeast-southwest trend of the copper-bearing veins and veinlets indicative of northwest-southeast extension, the northeast-vergence of the mineralized thrust faults and associated folds, and the mutually crosscutting relationships between mineralized veins/veinlets and thrusts are all consistent with a northeast-trending horizontal shortening direction and in agreement with structural interpretations of both in the San Marcos area and more regionally (Chávez-Cabello, 2005; Chávez-Cabello et al., 2005, 2007; Molina-Garza et al., 2008; Bolaños-Rodríguez, 2006; Figure 5). In the broader Monclova region, principal vein trends in numerous sediment-hosted stratiform prospects containing one or more of copper, silver, lead, zinc, fluorite, and barite are also oriented northeast-southwest (González-Ramos et al., 1997; Barbosa-Luna et al., 1998; Ramírez-Gutiérrez and Ramos-Anleu, 2008), a preferred direction that is taken to indicate that the prevalent stress conditions were everywhere the same for all mineralization styles. Additionally, in the vicinity of the northwest-trending San Marcos fault, copper-, lead-, and zinc-bearing veins associated with sediment-hosted mineralization are oriented predominantly subparallel to the fault (e.g., Ramírez-Gutiérrez and Ramos-Anleu, 2008), providing examples of the effective control on fluid upflow and discharge along this regional structure.

Hence, the principal structural and mineralization features of the San Marcos area confirm an intimate relationship between sediment-hosted stratiform copper-silver mineralization and structural deformation. Deformation in the region was previously interpreted to have taken place during two consecutive and progressive periods of Laramide orogenic activity (Chávez-Cabello, 2005; Chávez-Cabello et al., 2005, 2007; Bolaños-Rodríguez, 2006; Molina-Garza et al., 2008; Fitz-Díaz et al., 2018; Alonso-Manuel et al., 2020; Figure 9): an early thin-skinned structural event, characterized by shallow, bedding-parallel thrusting and associated fault-bend folding along the frontal portion of regional, northeast-vergent detachment structures of the Coahuila block; and, a second event, with kinematic inversion of deep-seated, basin-bounding faults and generation of basement-rooted, high-angle brittle faults under a thick-skinned tectonic regime. Paleogene-age Laramide activity along the San Marcos fault system took place predominantly during the second event and was responsible for the uplift of Paleozoic basement blocks, involving from 1300 to $3000 \mathrm{~m}$ of vertical displacement and $\sim 500 \mathrm{~m}$ of horizontal shortening, under a horizontal, northeast- to north-northeast-directed principal $(\sigma 1)$ stress field (McKee et al., 1990; Chávez-Cabello, 2005; Bolaños-Rodríguez, 2006; Alonso-Manuel et al., 2020). This activity occurred contemporaneously with tectonism along the Mexican fold-thrust belt and orogen-wide uplift, which triggered massive detrital sedimentation in paired foreland basins (Chávez-Cabello $e t$ al., 2006; Gray and Lawton, 2011; Fitz-Díaz et al., 2011, 2014, 2016, 2018; Ramírez-Peña and Chávez-Cabello, 2017; Juárez-Arriaga et al., 2019a, 2019b; Davison et al., 2020; Gray et al., 2020; Williams et al., 2020).

The presence of mineralized veins and veinlets accompanying the disseminated stratiform copper mineralization at San Marcos is taken as evidence that copper-bearing fluids operated at various scales during the deformation history of the host strata, with vein/veinlet emplacement induced by tectonic stress imposed by the Laramide orogeny. Hence, these veins and veinlets represent the episodic passage of far-travelled copper-bearing fluids and their propagation and growth as overpressured mobile hydrofractures (e.g., Oliver and Bons, 2001; Bons et al., 2012), which in the study area occurred at and near an important upper crustal discontinuity: the regional San Marcos fault system at the boundary between the Coahuila block and Sabinas basin (e.g., García-Alonso et al., 2011; Figure 1). Indeed, the San Marcos fault system originated in the Jurassic as a basin-bounding structure during the opening of the Gulf of Mexico, continued as a growth fault during Sabi- 
nas basin sedimentation, and was finally inverted as a series of reverse faults and fault panels during Laramide contraction in the Paleogene (McKee et al., 1990; Chávez-Cabello, 2005; Chávez-Cabello et al., 2005, 2007; Bolaños-Rodríguez, 2006; FitzDíaz et al., 2018; Alonso-Manuel et al., 2020).

By analogy with sediment-hosted stratiform copper deposits elsewhere, the mineralized veins and veinlets present in the San Marcos area imply cogenesis between the two styles of mineralization (e.g., Sillitoe et al., 2010, 2017a, 2017b). Hence, the described crosscutting relationships between stratiform mineralization, mineralized veins and veinlets, and the tectonic structures affecting the host sequence suggest that emplacement of the copper-silver mineralization at San Marcos occurred during the transition from shallow-angle slip and thrusting to high-angle, basement-involved faulting (Figure 9). Both deformation and mineralization were promoted by the prevalent northeast-southwest-oriented, horizontal shortening during inversion of the Sabinas basin in the Paleogene (e.g., Chávez-Cabello, 2005; Chávez-Cabello et al., 2005, 2006, 2007; Molina-Garza et al., 2008) which, elsewhere in the Mexican fold-thrust belt, propagated progressively to the east between the Late Cretaceous ( $90 \mathrm{Ma}$, Turonian) and the middle Eocene (40 Ma, Lutetian; Fitz-Díaz et al., 2011, 2014, 2018; Juárez-Arriaga et al., 2019a; Gray et al., 2020).

Hence, contrary to previous syngenetic (Rivera-Martínez, 1993) or syndiagenetic (García-Alonso et al., 2011) proposals for the timing of the sediment-hosted copper-silver mineralization in the area, the geologic evidence indicates that mineralization was predominantly epigenetic and took place $\sim 70$ to 40 m.yr. after sedimentation of the host strata of the San Carlos Formation and the establishment of the redoxcline with the carbonate rocks of the Cupido Formation in the Early Cretaceous. Such timing would be congruent with a gravity-driven fluid-flow model for the origin of the mineralization associated with tectonic loading and crustal thickening resulting from the eastward migration of the Laramide orogenic front in northeastern Mexico (e.g., Fitz-Díaz et al., 2011) and possibly elsewhere in contiguous parts of the southwest US. For example, the emplacement of the sediment-hosted stratiform copper mineralization in strata of the Paradox basin exposed in the Colorado Plateau of Utah and Colorado (e.g., Barton et al., 2008) has also been assigned a Laramide timing (early Eocene; 51 to $48 \mathrm{Ma}$ ), as suggested by the isotopic dates obtained from fault-controlled and disseminated copper-bearing products (Kirk et al., 2020).

Although multiple driving forces can be responsible for fluid movement during basin evolution (e.g., Kyser, 2007; Boiron et al., 2010; Barton et al., 2018), fluid expulsion, convective circulation, and upward brine migration along regional structural channel ways such as the San Marcos fault system (e.g., Yang et al., 2004), were likely best accomplished by tectonic squeezing during Laramide contraction and fault inversion in the Mexican orogen (e.g., Oliver, 1992; Sibson, 1995; Zhang et al., 2006; Fitz-Díaz et al., 2011; Gibson et al., 2017; Sillitoe et al., 2017a, 2017b). In the case of the San Marcos area, one additional source of heat to sustain the upward convection and transport of the dense, deeply circulating, copper-bearing brines could have been provided by the arc magmatism of the Candela-Monclova belt, which migrated eastward across the region contemporaneously with deformation (Chávez-Cabello, 2005; Molina-Garza et al., 2008; Chávez-Cabello et al., 2009; Figure 4a). Although such a relationship is possible, because many of these intrusions are mineralized with copper, silver, lead, and zinc (e.g., González-Ramos et al., 1997), it should be noted that elsewhere in the Mesozoic basins hosting stratiform base-metal mineralization in northeastern Mexico, a genetic relationship with magmatism is absent (e.g., Trittla et al., 2006, 2007; González-Sánchez et al., 2007, 2009; González-Partida et al., 2017).

\subsection{IMPLICATIONS FOR THE TIMING OF SEDIMENT-HOSTED STRATIFORM BASE METAL MINERALIZATION IN THE REGION}

In common with many sediment-hosted copper deposits elsewhere, the fluids responsible for mineralization at San Marcos were dense, near neu- 
tral, saline, $\mathrm{Na}-\mathrm{Ca}$-bearing, moderately oxidized, chloride-dominant basinal brines that likely infiltrated deeply in the basin and its basement (e.g., Rose, 1976; Jowett, 1991; Brown, 2014). Fluid temperatures, salinities, and compositions (García-Alonso et al., 2011) were similar to those of other sediment-hosted stratiform copper-silver deposits in the region (e.g., Las Vigas, Chihuahua; González-Partida et al., 2017). The processes that gave rise to the copper mineralization were also similar to those in other deposits of the class, whereby sulfate was reduced by hydrocarbons either bacterially or inorganically, in the latter case via thermochemical reduction (García-Alonso et al., 2011; González-Partida et al., 2013, 2017).

Given that the fluid characteristics and processes responsible for regional base-metal-bearing MVT mineralization in the Sabinas basin were

(a)
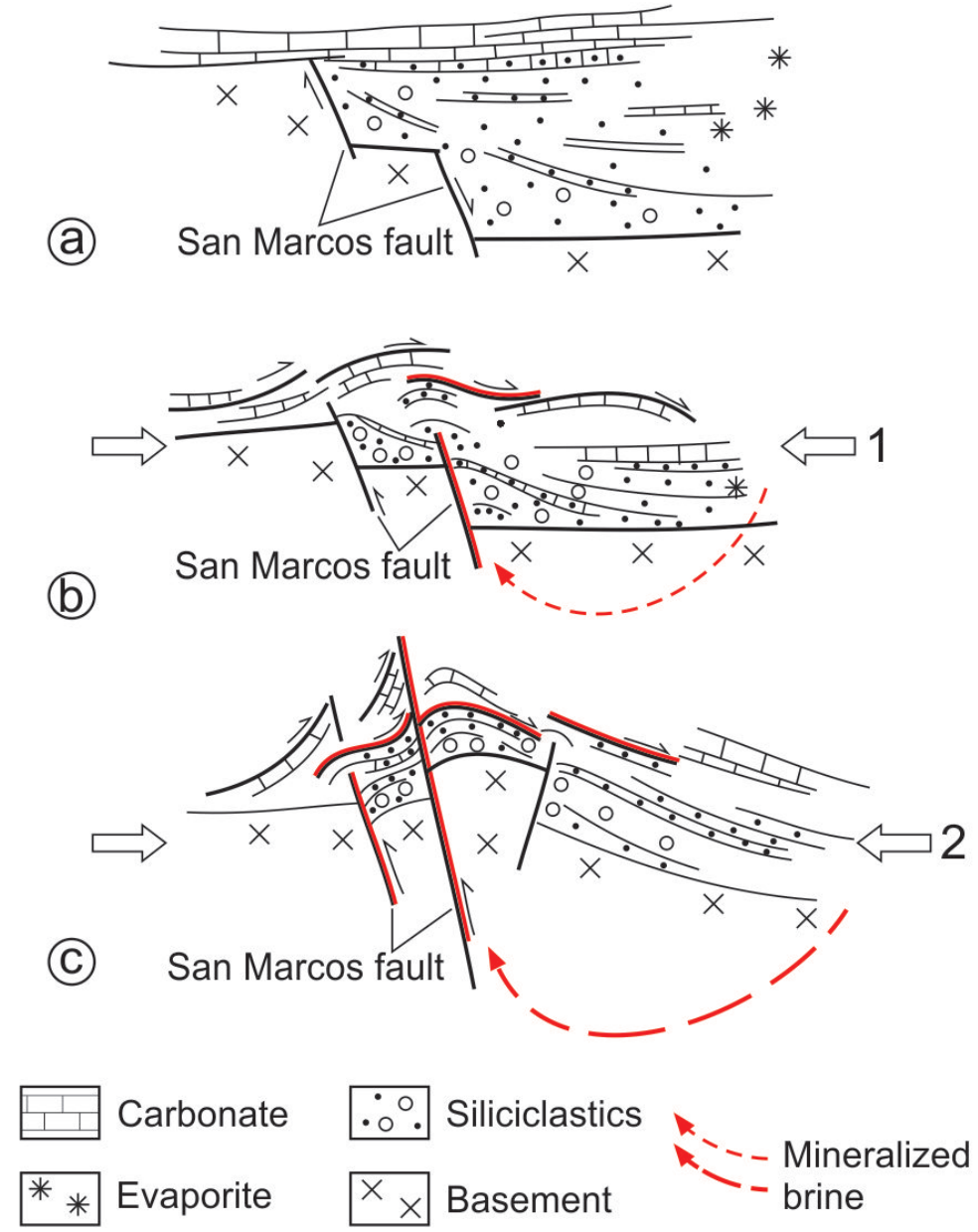

Figure 9 Schematic representation of the emplacement of the sediment-hosted stratiform copper-silver mineralization in the San Marcos area. a). The original basin configuration, with stair-step bounding faults (e.g., the original San Marcos fault system) and corresponding basin fill. $b$ ). First event (1) of shallow-angle, mostly bedding-parallel tectonism of thin-skinned style during early Laramide deformation promoted initial squeezing and fluid migration in the basin. c). Second event (2) of high-angle, reverse faulting under thick-skinned structural conditions, during which the regional basin-bounding faults were inverted as brittle faults, with participation of basement units. The sediment-hosted stratiform copper-silver mineralization in the San Marcos area was emplaced broadly synchronously with deformation, but predominantly accompanied the second deformation event, as highlighted by the larger red arrow, during wholesale basin inversion resultant from the advancing Laramide tectonic front into the region. See text for further discussion. The timing and styles of deformation incorporate the concepts of Chávez-Cabello (2005), Chávez-Cabello et al. (2005, 2007), and Bolaños-Rodríguez (2006). 
strikingly similar, a common origin and a predominantly syntectonic timing have been proposed for both sediment-hosted stratiform copper and MVT mineralization (González-Sánchez et al., 2007, 2009; González-Partida et al., 2013; Camprubí, 2017), with a postulated permissive interval of formation between $\sim 110 \mathrm{Ma}$ (Albian) and $30 \mathrm{Ma}$ (Oligocene) resulting from a combination of Sevier and Laramide orogenic contraction (e.g., Camprubí, 2017). Indeed, the uplift of the Cretaceous carbonate platform sequences is likely to have resulted in important karstification that would have contributed to permeability and ground preparation for the incoming MVT fluids. If such a common origin for both deposit styles is correct, it follows that the bulk of the MVT mineralization in the Sabinas basin was not only the product of widespread Laramide shortening and deformation (González-Sánchez et al., 2009), but also that its timing can be more precisely constrained by the wholesale basin inversion event in the Paleocene-Eocene from $\sim 60$ to $40 \mathrm{Ma}$. This is coincident with large-scale fluid circulation in basins of central and northeastern Mexico (Laubach and Ward, 2006; Fitz-Díaz et al., 2011, 2018; Williams et al., 2020).

\subsection{IMPLICATIONS FOR THE TECTONIC SETTING OF SEDIMENT-HOSTED STRATIFORM GOPPER- SILVER MINERALIZATION IN THE REGION}

Current reconstructions of the tectonic setting of central and eastern Mexico during the early phases of the Laramide orogeny in the Late Cretaceous (Turonian-Maastrichtian) postulate that a large, compartmentalized, predominantly marine foreland basin (collectively named Mexican foreland basin; Juárez-Arriaga et al., 2019a, 2019b) was established along the eastern front of the Mexican fold-thrust belt (Centeno-García, 2017; Fitz-Díaz et al., 2018; Juárez-Arriaga et al., 2019a, 2019b; Davison et al., 2020; Pindell et al., 2020; Gray et al., 2020). Between $\sim 90 \mathrm{Ma}$ (Turonian) and 40 $\mathrm{Ma}$ (Lutetian), this basin received a massive input of siliciclastic detritus, in excess of $6 \mathrm{~km}$ in thickness, principally from the erosion of the Mexi- can orogen that was undergoing contraction and uplift (Lawton et al. 2009; Juárez-Arriaga 2019b; Davidson et al., 2020; Gray et al., 2020). Hence, the Paleogene sediment-hosted stratiform copper-silver mineralization and the lead-zinc-fluorine-barium-strontium MVT deposits of the Sabinas and adjacent basins formed contemporaneously with regional foreland sedimentation, at a time when their original intracratonic rift setting consequent upon opening of the Gulf of Mexico was undergoing important tectonic reorganization. Such a marine environment would help to explain the predominant seawater affinity of the mineralizing fluids responsible for the sediment-hosted copper mineralization in the San Marcos area and regionally (García-Alonso et al., 2011; González-Partida et al., 2017), whereas the meteoric component would result from the ingress of meteoric water in the highlands of the Mexican orogen (Fitz-Díaz et al., 2011).

\section{Conclusions}

The sediment-hosted stratiform copper-silver mineralization in the San Marcos area of Coahuila is characterized by disseminations, veins, and veinlets that are comprised everywhere by the same copper-bearing sulfide and oxide mineral assemblages. The mineralization is principally controlled by an Early Cretaceous redox boundary located at the transition between footwall siliciclastic red beds of the San Marcos Formation and hanging-wall carbonate strata of the Cupido Formation. Additional manifestations of the same mineralization style in lower horizons of the San Marcos Formation and in Late Jurassic strata of Sierra El Granizo beds, along with copper-bearing veins in basement blocks of Permian-Triassic age show that mineralization spans a stratigraphic thickness of $\sim 3,000 \mathrm{~m}$ of basin fill.

The geologic and structural features of the sediment-hosted stratiform copper-silver mineralization in the San Marcos area corroborate a synorogenic timing of emplacement during inver- 
sion of the Sabinas basin triggered by Laramide contractional tectonism. In accord with the orogen-wide deformation chronology, the preferred timing for the mineralization at San Marcos, and elsewhere in the larger Monclova region, is Paleocene-Eocene ( $60-40 \mathrm{Ma})$ coincident with voluminous fluid circulation in the basins of northeastern Mexico. This timing is equally applicable to the MVT mineralization of various styles, but mainly of lead-zinc-silver, if the previously established genetic and spatial relationships between the two mineralization types are correct.

Hence, although the Early Jurassic to earliest Late Cretaceous ( 190-90 Ma) sedimentary fill of the Sabinas basin took place in a pericratonic setting initially associated with opening of the Gulf of Mexico, sediment-hosted stratiform copper-silver (and MVT) mineralization occurred during orogenic uplift and conversion of the original basin into a paired orogen-foreland setting, a situation remarkably similar to the tectonic environment of the Cambrian-aged sediment-hosted stratiform copper mineralization in the Zambian Copperbelt (Sillitoe et al., 2017a, 2017b).

\section{Acknowledgments}

I thank Dick Sillitoe for his thorough review of the manuscript, Carlos Escalante for field discussions, and the comments by an anonymous referee. Héctor Poblete drafted the accompanying figures and Grupo Minero Panuco organized fieldwork logistics.

\section{References}

Aleinikoff, J.N., Hayes, T.S., Evans, K.V., Mazdab, F.K., Pillers, R.M., Fanning, G.M., 2012, SHRIMP $\mathrm{U}-\mathrm{Pb}$ ages of xenotime and monazite from the Spar Lake red bedassociated $\mathrm{Cu}-\mathrm{Ag}$ deposit, western Montana: Implications for ore genesis: Economic Geology, 107 (6), 1251-1274. https://doi. org/10.2113/econgeo.107.6.1251
Alonso-Manuel, F., Fitz-Díaz, E., GutiérrezNavarro, R., 2020, Estimación de desplazamiento mínimo en fallas inversas de alto ángulo: caso de estudio en la Falla de San Marcos, Coahuila: Boletín de la Sociedad Geológica Mexicana, 72 (1), A031019. http://dx.doi.org/10.18268/ BSGM2020v72nla031019

Annels, A.E., 1989, Ore genesis in the Zambian Copperbelt, with particular reference to the northern sector of the Chambishi basin: Geological Association of Canada Special Paper, 36, 427-452.

Barbosa-Luna, D., 1998, Informe de la carta geológico-minera y geoquímica Hoja Tanque Nuevo, G13-B69, Estado de Coahuila, escala 1:50,000. Pachuca, Hidalgo, Secretaría de Comercio y Fomento Industrial, Coordinadora General de Minería: Consejo de Recursos Minerales, $79 \mathrm{p}$.

Barbosa-Luna, D., Martínez-Ramos, G.J., Santiago-Carrasco, B., Izaguirre-Ramos, M.A., Gracia-Valadez, M.J., 1998, Informe de la carta geológico-minera y geoquímica Hoja Tlahualillo de Zaragoza G13-6, escala 1:250000, Estados de Coahuila, Durango y Chihuahua: Consejo de Recursos Minerales, Gerencia de exploración Geológica, Oficina regional Saltillo, 136p.

Barbosa-Luna, D., Martínez-Ramos, G.J., Santiago-Carrasco, B., Izaguirre-Ramos, M.A., Gracia-Valadez, M.J. 2008, Carta geológico-Minera Tlahualillo de Zaragoza G13-6, escala 1:250000, Coahuila, Durango y Chihuahua. Second edition, September 2008. Pachuca, Hidalgo, Servicio Geológico Mexicano, Coordinación General de Minería, Secretaría de Economía.

Barboza-Gudiño, J.R., Tristán-González, M., Torres-Hernández, J.R., 1999, Tectonic setting of pre-Oxfordian units from central and northeastern Mexico. A review. In Bartolini, C.,Wilson, J.L., Lawton, T.F., (eds.), Mesozoic sedimentary and tectonic history of north-central 
Mexico: Geological Society of America Special Paper, 340, 197-210. https://doi. org/10.1130/0-8137-2340-x.197

Bartholomé, P., Evrard, P., Katekesha, F., LopezRuiz, J., Ngongo, M., 1972, Diagenetic oreforming processes at Kamoto, Katanga, Republic of the Congo. In Amstutz, G.C., Bernard, A.J., (eds.), Ores in sediments: Springer-Verlag, Berlin, 21-41. https://doi. org/10.1007/978-3-642-65329-2_3

Barton, M.D., Barton, I.F., Thorson, J.P., 2018, Paleofluid flow in the Paradox Basin: Introduction: Society of Economic Geologists, Guidebook Series, 59, 1-12.

Bird, D.E., Burke, K., Hall, S.A., Casey, J.F., 2005, Gulf of Mexico tectonic history: Hotspot tracks, crustal boundaries, and early salt distribution: American Association of Petroleum Geologists Bulletin, 89, 311-328. https://doi.org/10.1306/10280404026

Boiron, M.C., Cathelineau, M., Richard, A., 2010, Fluid flows and metal deposition near basement /cover unconformity: lessons and analogies from $\mathrm{Pb}-\mathrm{Zn}-\mathrm{F}-\mathrm{Ba}$ systems for the understanding of Proterozoic $\mathrm{U}$ deposits: Geofluids, 10, 270-292. https:// doi.org/10.1111/j.1468-8123.2010.00289.x

Bolaños-Rodríguez,D.E., 2006, Análisis estructural en el puerto de las sierras La Fragua, El Granizo, San Marcos-Pinos y áreas aledañas en la parte central de Coahuila. Facultad de Ingeniería, Universidad Nacional Autónoma de México, Degree thesis, 74p.

Bons, P.D., Elburg, M.A., Gomez-Rivas, E., 2012, A review of the formation of tectonic veins and their microstructures: Journal of Structural Geology, 43, 33-62. https://doi. org/10.1016/j.jsg.2012.07.005

Brems, D., Muchez, Ph., Sikazwe, O., Mukumba, W., 2009, Metallogenesis of the Nkana copper-cobalt South Orebody, Zambia: Journal of African Earth Sciences, 55, 185-196. https://doi.org/10.1016/j. jafrearsci.2009.04.003

Brown, A.C., 1981, The timing of mineralization in stratiform copper deposits. In Wolf,
K.H., (ed.), Handbook of strata-bound and stratiform ore deposits, Part III, Volume 9. Elsevier Scientific Publishing Company, Amsterdam, 1-23. https://doi.org/10.1016/ B978-0-444-41824-1.50004-9

Brown, A.C., 1992, Sediment-hosted stratiform copper deposits: Geoscience Canada, 19, 125-141.

Brown, A.C., 2014, Low-temperature sedimenthosted copper deposits. In Holland, H.D. and Turekian, K.K., (eds.), Treatise on Geochemistry, Oxford: Elsevier, Second Edition, 13, 251-271. https://doi. org/10.1016/b978-0-08-095975-7.01110-4

Brown, A.C., 2017, Constraints on conceptual and quantitative modeling of early diagenetic sediment-hosted stratiform copper mineralization: Minerals, 7 (10), 192. https://doi.org/10.3390/min7100192

Brummer, J.J., 1955, The geology of the Roan Antelope orebody: Transactions of the Institution of Mining and Metallurgy, 64, 257-318.

Buckley, A.N., Woods, R., 1984, An X-ray photoelectron spectroscopic study of the oxidation of chalcopyrite: Australian Journal of Chemistry, 37, 2403-2413. https://doi. org/10.1071/ch9842403

Cailteux, J.L.H., Kampunzu, A.B., Lerouge, C., Kaputo, A.K., Milesi, J.P., 2005, Genesis of sediment-hosted stratiform copper-cobalt deposits, Central African Copperbelt: Journal of African Earth Sciences, 42, 13-158. https://doi.org/10.1016/j. jafrearsci.2005.08.001

Camprubí, A., 2013, Tectonic and metallogenic history of Mexico. In Colpron, M., Bissig, T., Rusk, B. G., Thompson, J. F. H. (eds.), Tectonics, Metallogeny, and Discovery: The North American Cordillera and Similar Accretionary Settings, Society of Economic Geologists, Special Publication, 17, 201-243. https://doi.org/10.5382/SP.17.06

Camprubí, A., 2017, The metallogenic evolution in Mexico during the Mesozoic, and its bearing in the Cordillera of western North 
America: Ore Geology Reviews, 81, 1193-1214. https://doi.org/10.1016/j. oregeorev.2015.11.007

Chávez-Cabello, G., 2005, Deformación y magmatismo Cenozoico en el sur de la Cuenca de Sabinas, Coahuila, México. Juriquilla, Querétaro, Universidad Nacional Autónoma de México, Centro de Geociencias, Ph.D thesis, 226p.

Chávez-Cabello, G., Aranda-Gómez, J.J., MolinaGarza, R.S., Cossío-Torres, T., ArvizuGutiérrez, I.R., González-Naranjo, G.A., 2005, La falla San Marcos: una estructura jurásica de basamento multirreactivada del noreste de México: Boletín de la Sociedad Geológica Mexicana, 57 (1), 27-52. https:// doi.org/10.18268/bsgm2005v57n la2

Chávez-Cabello, G., Aranda-Gómez, J.J., MolinaGarza, R.S., Cossío-Torres, T., ArvizuGutiérrez, I.R., González-Naranjo, G.A., 2007, The San Marcos fault: A Jurassic multireactivated basement structure in northeastern México: Geological Society of America, Special Paper, 422, 261-286. https://doi.org/10.1130/2007.2422(08)

Chávez-Cabello, G., Aranda-Gómez, JJ., IriondoPerrone, A., 2009, Culminación de la orogenia Laramide en la cuenca de Sabinas, Coahuila, México: Boletín de la Asociación Mexicana de Geólogos Petroleros, 54 (1), 78-89.

Clark, K.F., de la Fuente L., F.E., 1978, Distribution of mineralization in time and space in Chihuahua, Mexico: Mineralium Deposita, 13, 27-49. https://doi.org/10.1007/ bf00202906

Centeno-García, E., 2017, Mesozoic tectonomagmatic evolution of Mexico: An overview: Ore Geology Reviews, 81, 1035-1052. https://doi.org/10.1016/j. oregeorev.2016.10.010

Davison, I., Pindell, J., Hull, J., 2020, The basins, orogens and evolution of the southern Gulf of Mexico and northern Caribbean: Geological Society, London, Special Publications,
504, 1-27. https://doi.org/10.1144/ SP504-2020-218

Dewaele, S., Muchez, Ph., Vets, J., FernandezAlonzo, M., Tack, L., 2006, Multiphase origin of the $\mathrm{Cu}$-Co ore deposits in the western part of the Lufilian fold-and-thrust belt, Katanga (Democratic Republic of Congo): Journal of African Earth Sciences, 46, 455-469. https:// doi.org/10.1016/j.jafrearsci.2006.08.002

Dickinson, W.R., Lawton, T.F., 2001, Carboniferous to Cretaceous assembly and fragmentation of Mexico: Geological Society of America Bulletin, 113 (9), 1142$1160 . \quad$ https://doi.org/10.1130/00167606(2001)1 13<1142: CTCAAF $>2.0$. $\mathrm{CO} ; 2$

Eguiluz de Antuñano, S.E., Aranda-García, M., Marrett, R., 2000, Tectónica de la Sierra Madre Oriental, México: Boletín de la Sociedad Geológica Mexicana, 53 (1), 1-26. http://dx.doi.org/10.18268/ BSGM2000v53nlal

Eguiluz de Antuñano, S.E., 2001, Geologic evolution and gas resources of the Sabinas Basin in northeastern México: American Association of Petroleum Geologists Memoir, 75, 241-270. https://doi.org/10.1306/ $\mathrm{m} 75768 \mathrm{c} 10$

El Desouky, H.A., Muchez, P., Cailteux, J., 2009, Two Cu-Co sulphide phases and contrasting fluid systems in the Katanga Copperbelt, Democratic Republic of Congo: Ore Geology Reviews, 36, 315-332. https://doi. org/10.1016/j.oregeorev.2009.07.003

Engelder, T., 1985, Loading paths to joint propagation during a tectonic cycle: an example from the Appalachian Plateau, U.S.A.: Journal of Structural Geology, 7, 459-476. https://doi. org/10.1016/0191-8141(85)90049-5

Fastovsky, D.E.O., Hermes, D., Strater, N.H., Bowring, S.A., Clark, J.M., Montellano, M., Hernández, R., 2005, Pre-Late Jurassic, fossil-bearing volcanic and sedimentary red beds of Huizachal Canyon, 
Tamaulipas, Mexico. In Anderson, T.H., Nourse, J.A., McKee, J.W.,Steiner, M.B. (eds.), The Mojave-Sonora Megashear Hypothesis: Development, Assessment, and Alternatives: Geological Society of America Special Paper, 393, 259-282. https://doi. org/10.1130/0-8137-2393-0.401

Fitz-Diaz, E., van der Pluijm, B., 2013, Fold dating: A new Ar/Ar illite dating application to constrain the age of deformation in shallow crustal rocks: Journal of Structural Geology, 54, 174-179. https://doi.org/10.1016/j. jsg.2013.05.011

Fitz-Díaz, E., Hudleston, P., Kirschner, D., Siebenaller, L., Camprubí, T., Tolson, G., Pi Puig, T., 2011, Insights into fluid flow and water-rock interaction during deformation of carbonate sequences in the Mexican foldthrust belt: Journal of Structural Geology, 33, 1237-1253. https://doi.org/10.1016/j. jsg.2011.05.009

Fitz-Díaz, E., Hudleston, P., Tolson, G., van der Pluijm B. 2014, Progressive, episodic deformation in the Mexican Fold-Thrust Belt (central Mexico): evidence from isotopic dating of folds and faults: International Geology Review, 56, 734-755. https://doi.or $\mathrm{g} / 10.1080 / 00206814.2014 .896228$

Fitz-Díaz, E., Hall, C.M., van der Pluijm, B.A., 2016, XRD-based ${ }^{40} \mathrm{Ar} /{ }^{39} \mathrm{Ar}$ age correction for fine-grained illite, with application to folded carbonates in the Monterrey Salient (northern Mexico): Geochimica et Cosmochimica Acta, 181, 201-216. https:// doi.org/10.1016/j.gca.2016.02.004

Fitz-Díaz, E., Lawton, T.M., Juárez-Arriaga, E., Chávez-Cabello, G., 2018, The CretaceousPaleogene Mexican orogen: Structure, basin development, magmatism and tectonics: Earth-Science Reviews, 183, 56-84. https:// doi.org/10.1016/j.earscirev.2017.03.002

García-Alonso, D., Canet, C., González-Partida, E., Villanueva-Estrada, R.E., Prol-Ledesma, R.M., Alfonso, P., Caballero-Martínez, J.A., Lozano-Santa Cruz, R., 2011, The
Cretaceous sediment-hosted copper deposits of San Marcos (Coahuila, northeastern Mexico): an approach to ore-forming processes: Journal of South American Earth Sciences, 31, 432-443. https://doi. org/10.1016/j.jsames.2011.02.012

Garlick, W.G., 1961, Ore genesis. The syngenetic theory. In Mendelsohn, F. (ed.), The geology of the Northern Rhodesian Copperbelt. MacDonald \& Co (Publishers) Ltd, London, 146-165.

Garlick, W.G., 1967, Criteria for recognition of syngenetic sedimentary mineral deposits and veins formed by their remobilization. Commonwealth Mining and Metallurgical Congress, 8th, Australia and New Zealand, 1965, Proceedings - General, 6, 1393-1418.

Ghandi, S.S., Brown, A.C., 1975, Cupriferous shales of the Adeline Island Formation, Seal Lake Group, Labrador: Economic Geology, 70, 145-163. https://doi.org/10.2113/ gsecongeo.70.1.145

Gibson, G.M., Hutton, L.J., Holzschuh, J., 2017, Basin inversion and supercontinent assembly as drivers of sediment-hosted $\mathrm{Pb}^{-}$ $\mathrm{Zn}$ mineralization in the Mount Isa region, northern Australia:Journal of the Geological Society, 174 (4), 773-786. https://doi. org/10.1144/jgs2016-105

Goldhammer, R.K., 1999, Mesozoic sequence stratigraphy and paleogeographic evolution of northeast Mexico: Geological Society of America Special Paper, 340, 1-58. https:// doi.org/10.1130/0-8137-2340-x.1

González-Partida, E., Camprubí, A., GonzálezRuiz, L.E., Canet, C., Pura, A., PiedadSánchez, N., 2013, Los depósitos estratoligados de cobre en el noreste de México: características genéticas a partir del análisis de los fluidos mineralizantes. Acapulco, Guerrero, México, October 16-19, 2013, XXX Convención Internacional de Minería, Asociación de Ingenieros de Minas, Metalurgistas y Geólogos de México, A.G. (AIMMGM), Acta de Sesiones, 105-110. 
González-Partida, E., Camprubí, A., Pironon, J., Alfonso, P., Cienfuegos-Alvarado, E., Morales-Puente, P.A., Canet, C., GonzálezRuiz, L.E., Díaz-Carreño, E.H., 2017, Modelo de formación de los yacimientos estratoligados de $\mathrm{Cu}$ en lechos rojos de Las Vigas (Chihuahua, México): Boletín de la Sociedad Geológica Mexicana, 69 (3), 611-635. https://doi.org/10.18268/ bsgm2017v69n3a6

González-Ramos, A., Barbosa-Luna, D., Santiago-Carrasco, B., Izaguirre-Ramos, M., 1997, Informe final complementario a la cartografía geológico, minera y geoquímica, escala 1:250000, Carta Monclova clave G14-4, Estados de Coahuila y Nuevo León. Consejo de Recursos Minerales, Gerencia de Exploración Geológica, Oficina Regional Saltillo, 101p.

González-Ramos, A., Martínez-Ramos, C., Izaguirre-Ramos, M.A., Barbosa-Luna, D., Santiago-Carrasco, B., 2008, Carta geológicominera Monclova, G14-4, Coahuila y Nuevo León, escala 1:250000. Second edition, September 2008. Pachuca, Hidalgo, Servicio Geológico Mexicano, Coordinación General de Minería, Secretaría de Economía.

González-Sánchez, F., Puente-Solís, R., GonzálezPartida, E., Camprubí, A., 2007, Estratigrafía del Noreste de México y su relación con los yacimientos estratoligados de fluorita, barita, celestina y Zn-Pb: Boletín de la Sociedad Geológica Mexicana, 59 (1), 43-62. https:// doi.org/10.18268/bsgm2007v59nla4

González-Sánchez, F., Camprubí, A., GonzálezPartida, E., Puente-Solís, R., Canet, C., Centeno-García, E., Atudorei, V., 2009, Regional stratigraphy and distribution of epigenetic stratabound celestine, fluorite, barite, and $\mathrm{Zn}-\mathrm{Pb}$ deposits in the MVT province of northeastern Mexico: Mineralium Deposita, 44, 343-361. https:// doi.org/10.1007/s00126-008-0212-4

Gray, G.G., Lawton, T.F., 2011, New constraints on timing of Hidalgoan (Laramide) deformation in the Parras and La Popa basins, NE Mexico: Boletín de la Sociedad Geológica Mexicana, 63, 333-343. https:// doi.org/10.18268/bsgm2011v63n2a13

Gray, G.G., Villagomez, D., Pindell, J., MolinaGarza, R., O’Sullivan, P., Stockli, D., Farrell, W., Blank, D., Schuba, J., 2020, Late Mesozoic and Cenozoic thermotectonic history of eastern, central and southern Mexico as determined through integrated thermochronology, with implications for sediment delivery to the Gulf of Mexico: Geological Society, London, Special Publications, 504, 255-283. https://doi. org/10.1144/sp504-2019-243

Hayes, T.S., Cox, D.P., Piatak, N.M., Seal, R.R., II, 2015, Sediment-hosted stratabound copper deposit model: U.S. Geological Survey, Scientific Investigations Report 20105070-M, 147p. https://doi.org/10.3133/ sir20105070M

Hayes, T.S., Einaudi, M.T., 1986, Genesis of the Spar Lake strata-bound coppersilver deposit, Montana; Part 1, Controls inherited from sedimentation and preore diagenesis: Economic Geology, 81 (8), 1899-1931. https://doi.org/10.2113/ gsecongeo.81.8.1899

Hitzman, M., Kirkham, R., Broughton, D., Thorson, J., Selley, D., 2005, The sedimenthosted stratiform copper ore system. In Hedenquist, J.W., Thompson, J.F.H., Goldfarb, R.J., Richards, J.P. (eds.), Economic Geology One Hundredth Anniversary Volume 1905-2005: Society of Economic Geologists, Littleton, 609-642. https://doi.org/10.5382/av100.19

Hitzman, M.W., Selley, D., Bull, S., 2010, Formation of sedimentary rock-hosted stratiform copper deposits through Earth history: Economic Geology, 105 (3), 627-639. https://doi. org/10.2113/gsecongeo.105.3.627

Hitzman, M.W., Broughton, D., Selley, D., Woodhead, J., Wood, D., Bull, S., 2012, The Central African Copperbelt: diverse 
stratigraphic, structural, and temporal settings in the world's largest sedimentary copper district. In Hedenquist, J.W., Harris, M., Camus, F., (eds.), Geology and Genesis of Major Copper Deposits and Districts of the World: A Tribute to Richard H. Sillitoe, Society of Economic Geologists Special Publication 16, 487-514. https://doi. org/10.5382/sp. 16.19

Huang, X.W., Zhao, X.F., Qi, L., Zhou,M.F., 2013, $\mathrm{Re}-\mathrm{Os}$ and $\mathrm{S}$ isotopic constraints on the origins of two mineralization events at the Tangdan sedimentary rock-hosted stratiform $\mathrm{Cu}$ deposit, SW China: Chemical Geology, 347, 9-19. https://doi.org/10.1016/j. chemgeo.2013.03.020

Jowett, E.C., 1991, The evolution of ideas about the genesis of stratiform copper-silver deposits. Society of Economic Geologists, Economic Geology Monograph, 8, 117-132. https://doi.org/10.5382/mono.08.05

Juárez-Arriaga, E., Lawton, T.F., Stockli, D.F., Solari, L., Martens, U., 2019a, Late Cretaceous-Paleocene stratigraphic and structural evolution of the central Mexican fold and thrust belt, from detrital zircon (U$\mathrm{Th}) /(\mathrm{He}-\mathrm{Pb})$ ages: Journal of South American Earth Sciences, 95, 102264. https://doi. org/10.1016/j.jsames.2019.102264

Juárez-Arriaga, E., Lawton, T.F., Ocampo-Diaz, Y.Z.E., Stockli, D.F., Solari, L., 2019b, Sediment provenance, sediment-dispersal systems, and major arc-magmatic events recorded in the Mexican foreland basin, north-central and northeastern Mexico: International Geology Review, 61, 21182142. https://doi.org/10.1080/00206814.2 019.1581848

Kelepile, T., Betsi, T.B., Franchi, F., Shemang, E., 2020, Partitioning and distribution of silver in sediment-hosted $\mathrm{Cu}-\mathrm{Ag}$ deposits: Evidence from the Ghanzi-Chobe Belt portion of the Kalahari Copper Belt: Ore Geology Reviews, 124, 103663. https://doi. org/10.1016/j.oregeorev.2020.103663
Kirk, J., Ruiz, J., Reiners, P., Krantz, R., Downs, R., 2020, Rb-Sr and Re-Os ages of fault gouges and copper mineralization from the Paradox Basin, Utah. Goldschmidt Virtual Conference, 21-26 June 2020, Geochemical Society and the European Association of Geochemistry, abstract, $1 \mathrm{p}$.

Kirkham, R.V., 1989, Distribution, setting and genesis of sediment-hosted stratiform copper deposits: Geological Association of Canada, Special Paper, 36, 3-38.

Kyser, T.K., 2007,Fluids, basinanalysis, andmineral deposits: Geofluids, 7, 238-257. https://doi. org/10.1111/j.1468-8123.2007.00178.x

Laubach, S.E., Ward, M.E., 2006, Diagenesis in porosity evolution of opening-mode fractures, Middle Triassic to Lower Jurassic La Boca Formation, NE Mexico: Tectonophysics, 419, 75-97. https://doi.org/10.1016/j. tecto.2006.03.020

Lawton, T.F., Bradford, I.A., Vega, F.., Gehrels, G.E., Amato, J.M., 2009, Provenance of Upper Cretaceous-Paleogene sandstones in the foreland basin system of the Sierra Madre Oriental, northeastern Mexico, and its bearing on fluvial dispersal systems of the Mexican Laramide Province: Geological Society of America Bulletin, 121, 820-836. https://doi.org/10.1130/b26450.1

Lopez, R., Cameron, K.L., Jones, N.W., 2001, Evidence for Paleoproterozoic, Grenvillian, and Pan-African age Gondwanan crust beneath northeastern Mexico: Precambrian Research, 107, 195-214. https://doi. org/10.1016/s0301-9268(00)00140-6

Martini, M., Ortega-Gutiérrez, F., 2018, Tectonostratigraphic evolution of eastern Mexico during the break-up of Pangea: A review: Earth-Science Reviews, 183, 38-55. https:// doi.org/10.1016/j.earscirev.2016.06.013

Marton, G., Buffler, R.T., 2010, Jurassic Reconstruction of the Gulf of Mexico Basin: International Geology Review, 36, 545-586. https://doi. org/10.1080/00206819409465475 
McKee, J.W., Jones, N.W., Long, L.E., 1990, Stratigraphy and provenance of strata along the San Marcos fault, central Coahuila, Mexico: Geological Society of America Bulletin, 102, 593-614. https://doi. org/10.1130/0016-7606(1990)102\%3C059 3:saposa \%3E2.3.co;2

Mendelsohn, F., 1961, Metamorphism. In Mendelsohn, F.(ed.), The geology of the Northern Rhodesian Copperbelt; London, Macdonald \& Co. Ltd., 106-116.

Milton, J.E., Hickey, K.A., Gleeson, S.A., Falck, H., Allaz, J., 2017, In situ monazite dating of sediment-hosted stratiform copper mineralization in the Redstone Copper Belt, Northwest Territories, Canada: Cupriferous fluid flow late in the evolution of a Neoproterozoic sedimentary basin: Economic Geology, 112, 1773-1806. https:// doi.org/10.5382/econgeo.2017.4529

Molina-Garza, R.S., Chávez-Cabello, G., Iriondo, A., Porras-Vázquez, M.A., TerrazasCalderón, G.M., 2008, Paleomagnetism, structure and ${ }^{40} \mathrm{Ar} /{ }^{39} \mathrm{Ar}$ geochronology of the Cerro Mercado pluton, Coahuila: Implications for the timing of the Laramide orogeny in northern Mexico: Revista Mexicana de Ciencias Geológicas, 25 (2), 284-301.

Morley, G.K., von Hagke, C., Hansberry, R.L., Collins, A.S., Kanitpanyacharoen, W., King, R., 2017, Review of major shale-dominated detachment and thrust characteristics in the diagenetic zone: Part I, meso- and macro-scopic scale: Earth-Science Reviews, 173, 168-228. https://doi.org/10.1016/j. earscirev.2017.07.019

Muchez, P., Brems, D., Clara, E., De Gleyn, A., Lammens, L., Boyce, A., De Muynck, D., Mukumba, W., Sikazwe, O., 2010, Evolution of $\mathrm{Cu}-\mathrm{Co}$ mineralizing fluids at Nkana Mine, Central African Copperbelt, Zambia: Journal of African Earth Sciences, 58, 457-474. https://doi.org/10.1016/j. jafrearsci.2010.05.003
Ocampo-Díaz, Y.Z.E., Talavera-Mendoza, O., Jenchen, U., Valencia, V.A., MedinaFerrusquia, H.C., Guerrero-Suastegui, M., 2014, Procedencia de la Formación La Casita y la Arcosa Patula: implicaciones para la evolución tectono-magmática del $\mathrm{NE}$ de México entre el Carbonífero y el Jurásico: Revista Mexicana de Ciencias Geológicas, 31 (1), 45-63.

Oliver, J., 1992, The spots and stains of plate tectonics: Earth-Science Reviews, 32, 77-106. https://doi. org/10.1016/0012-8252(92)90013-j

Oliver, N. H., Bons, P. D., 2001, Mechanisms of fluid flow and fluid-rock interaction in fossil metamorphic hydrothermal systems inferred from vein-wallrock patterns, geometry and microstructure: Geofluids, 1 (2), 137-162.

Oummouch, A., Essaifi, A., Zayane, R., Maddi, O., Zouhair, M., Maacha, L., 2017, Geology and metallogenesis of the sediment-hosted $\mathrm{Cu}-\mathrm{Ag}$ deposit of Tizert (Igherm inlier, Anti-Atlas copperbelt, Morocco): Geofluids, 7508484. https://doi.org/10.1155/2017/7508484

Padilla y Sánchez, R.J., 1986, Post-Paleozoic tectonics of northeast Mexico and its role in the evolution of the Gulf of Mexico: Geofísica Internacional, 25 (1), 157-206. https://doi.org/10.22201/ igeof.00167169p.1986.25.1.804

Padilla y Sánchez, R.J., 2016, Late Triassic-Late Cretaceous paleogeography of Mexico and the Gulf of Mexico. Houston, Texas, December 8-9，2016，35 ${ }^{\text {th }}$ Annual Gulf Coast Section Society for Sedimentary Geology (SEPM) Foundation Perkins-Rosen Research Conference. http://www.gcssepm. org/conference/2016_PandA_Web.pdf

Perelló,J., Sillitoe, R.H., 2018, The Upper Peninsula copper province, Michigan: Geologic observations and genetic implications. Salta, Argentina, Proceedings of $15^{\text {th }}$ Quadrennial International Association on the Genesis of Ore Deposits (IAGOD) Symposium, 348-349. 
Perelló, J., Valencia, V.A., Cornejo, P., Clifford, J.A., Wilson, A.J., Collins, G., 2019, Timing of sediment-hosted $\mathrm{Cu}-\mathrm{Ag}$ mineralization in the Trans-Hudson orogen at Janice Lake, Wollaston Domain, Saskatchewan, Canada: Mineralium Deposita, 54, 81-100. https:// doi.org/10.1007/s00126-018-0806-4

Perelló, J., Clifford, J.A., Wilson, A.J., Kennedy, S., Creaser, R.A., Valencia, V.A., 2021, On the timing and metallogenic implications of the sediment-hosted stratiform coppersilver mineralization in the Creston Formation (Belt-Purcell Supergroup), British Columbia, Canada: Ore Geology Reviews, 131, 104032. https://doi.org/10.1016/j. oregeorev.2021.104032

Pindell, J., Kennan, L., 2009, Tectonic evolution of the Gulf of Mexico, Caribbean, and northern South America in the mantle reference frame: an update: Geological Society, London, Special Publications, 328, 1-55. https://doi.org/10.1144/sp328.1

Pindell, J., Villagómez, D., Molina-Garza, R., Graham, R., Weber, B., 2020, A revised synthesis of the rift and drift history of the Gulf of Mexico and surrounding regions in the light of improved age dating of the Middle Jurassic salt: Geological Society, London, Special Publications, 504, 29-76. https://doi.org/10.1144/SP504-2020-43

Price, J.G., Rubin, J.N., Tweedy, S.W., 1988, Geochemistry of the Vigas red-bed copper deposit, Chihuahua, Mexico: Economic Geology, 83, 1993-2001. https://doi. org/10.2113/gsecongeo.83.8.1993

Ramírez-Gutiérrez, J.G., Ramos-Anleu, P.D.A., 2008, Informe de la carta geológicominera Estanque de Palomas G14-A71, Escala 1:50000, Estado de Coahuila. Servicio Geológico Mexicano, Subdirección de Geología, Gerencia de Geología y Geoquímica, Subgerencia Regional Saltillo, $31 \mathrm{p}$.

Ramírez-Peña, C.F., Chávez-Cabello, G., 2017, Age and evolution of thin-skinned deformation in Zacatecas, Mexico: Sevier orogeny evidence in the Mexican foldthrust belt: Journal of South American Earth Sciences, 76, 101-114. https://doi. org/10.1016/j.jsames.2017.01.007

Richards, J.P., Krogh, T.E., Spooner, E.T.G., 1988, Fluid inclusion characteristics and $\mathrm{U}-\mathrm{Pb}$ rutile age of late hydrothermal alteration and veining at the Musoshi stratiform copper deposit, Central African Copper Belt, Zaire: Economic Geology, 83, 118-139. https://doi.org/10.2113/ gsecongeo.83.1.118

Rivera-Martínez, J.C., 1993, La mineralización de cobre en la región de Cuatrociénegas, Coah. y su posible relación con un depósito singenético. Consejo de Recursos Minerales, Gerencia Regional Zona Noreste, Residencia Coahuila, 8p.

Rose, A.W., 1976, The effect of cuprous chloride complexes in the origin of red-bed copper and related deposits: Economic Geology, 71, 1036-1048. https://doi.org/10.2113/ gsecongeo.71.6.1036

Rubio-Cisneros, I.I., Lawton, T.F., 2011, Detrital zircon $\mathrm{U}-\mathrm{Pb}$ ages of sandstones in continental red beds at Valle de Huizachal, Tamaulipas, NE Mexico: Record of EarlyMiddle Jurassic arc volcanism and transition to crustal extension: Geosphere, 7, 159-170. https://doi.org/10.1130/ges00567.1

Saintilan, N.J., Selby, D., Creaser, R.A., Dewaele, S., 2018, Sulphide Re-Os geochronology links orogenesis, salt and $\mathrm{Cu}-\mathrm{Co}$ ores in the Central African Copperbelt: Scientific Reports 8,14946. https://doi.org/10.1038/ s41598-018-33399-7

Sales, R.H., 1962, Hydrothermal versus syngenetic theories of ore deposition: Economic Geology, 57(5), 721-734. https:// doi.org/10.2113/gsecongeo.57.5.721

Salvador, A., 1987, Late Triassic-Jurassic paleogeography and origin of Gulf of Mexico Basin: American Association of Petroleum Geologists Bulletin, 71, 419-451. https://doi.org/10.1306/94886ec5-1704$11 \mathrm{~d} 7-8645000102 \mathrm{c} 1865 \mathrm{~d}$ 
Salvador, A., 1991, Triassic-Jurassic. In Salvador, A., (ed.), The Gulf of Mexico basin. Boulder, Colorado, Geological Society of America, The geology of North America, Vol. J, 131-181.

Salvador, A., Green, A., 1980, Opening of the Caribbean Tethys (Origin and development of the Caribbean and the Gulf of Mexico), In Auboin, J., Debelmas, J., Latreille, M., (eds.), Géologie des chaînes alpines issues de la Téthys: Bureau de Recherche Géologique et Minière, Mémoires, 115, 224-229.

Santiago-Carrasco, B., 1998, Informe de la carta geológico-minera y geoquímica Reforma G14-A61, Coahuila, escala 1:50000. Consejo de Recursos Minerales, Gerencia de Exploración Geológica, Oficina Regional Saltillo, 54p.

Selley, D., Broughton, D., Scott, R., Hitzman, M., Bull, S., Large, R., McGoldrick, P., Croaker, M., Pollington, N., Barra, F., 2005, A new look at the geology of the Zambian Copperbelt. In Hedenquist, J.W., Thompson, J. F. H., Goldfarb, R.J., Richards, J.P. (eds.), Economic Geology One Hundredth Anniversary Volume 1905-2005. Society of Economic Geologists, Littleton, 965-1000. https:// doi.org/10.5382/AV100.29

Sibson, R.H., 1995, Selective fault reactivation during basin inversion: potential for fluid redistribution through fault-valve action: Geological Society, London, Special Publications, 88, 3-19. https://doi. org/10.1144/gsl.sp.1995.088.01.02

Sillitoe, R.H., 2005, Supergene oxidized and enriched porphyry copper and related deposits: In Hedenquist, J.W., Thompson, J. F. H., Goldfarb, R.J., Richards, J.P., (eds.), Economic Geology One Hundredth Anniversary Volume 1905-2005. Society of Economic Geologists, Littleton, 723768. https://doi.org/10.5382/av100.22

Sillitoe, R.H., 2012, Copper provinces: Society of Economic Geologists, Special Publication,
16, 1-18. https://doi.org/10.5382/sp. 16.01

Sillitoe, R.H., Perelló, J., García, A., 2010, Sulfide-bearing veinlets throughout the stratiform mineralization of the Central African Copperbelt: Temporal and genetic implications: Economic Geology, 105 (8), 1361-1368. https://doi.org/10.2113/ econgeo.105.8.1361

Sillitoe, R.H., Perelló, J., Creaser, R.A., Wilton, J., Wilson, A.J., Dawborn, T., 2017a, Age of the Zambian Copperbelt: Mineralium Deposita, 52, 1245-1268. https://doi.org/10.1007/ s00126-017-0726-8

Sillitoe, R.H., Perelló, J., Creaser, R.A., Wilton, J., Wilson, A.J., Dawborn, T., 2017b, Reply to discussions of "Age of the Zambian Copperbelt" by Hitzman and Broughton and Muchez et al: Mineralium Deposita, 52, 1277-1281. https://doi.org/10.1007/ s00126-017-0769-x

Sweeney, M.A., Binda, P.L., and Vaughan, D.J., 1991, Genesis of the ores of the Zambian Copperbelt: Ore Geology Reviews, 6, 51-76. https://doi. org/10.1016/0169-1368(91)90032-3

Tritlla, J., Levresse, G., Corona-Esquivel, R., Banks, D., Lamadrid, H., Bourdet, J., 2006, Depósitos de $\mathrm{Pb}-\mathrm{Zn}$-Cu-Ba-F-Sr epigenéticos estratoligados en series sedimentarias en relación con salmueras de cuenca: depósitos de tipo "Mississippi Valley" (MVT) y similares en México: Boletín de la Sociedad Geológica Mexicana, 58 (1), 103-139. https://doi. org/10.18268/bsgm2006v58n1a4

Tritlla, J., Levresse, G., Corona-Esquivel, R., Banks, D., Lamadrid, H., Bourdet, J., Pinto-Linares, P.F., 2007, Epigenetic, lowtemperature, carbonate-hosted $\mathrm{Pb}-\mathrm{Zn}-\mathrm{Cu}-$ Ba-F-Sr deposits in México: a Mississippi Valley-type classification: Geological Society of America Special Paper, 422, 417-432. https://doi.org/10.1130/2007.2422(15)

Twite, F., Nex, P., Kinnaird, J., 2020, Strain fringes and strain shadows at Kamoa (DRC), implications for copper mineralization: Ore 
Geology Reviews, 122, 103536. https:// doi.org/10.1016/j.oregeorev.2020.103536

Vannucchi, P., Maltman, A., Bettelli, G., Clennell, B., 2003, On the nature of scaly fabric and scaly clay: Journal of Structural Geology, 25, 673-688. https://doi.org/10.1016/ s0191-8141(02)00066-4

Vannucchi, P., 2019, Scaly fabric and slip within fault zones: Geosphere, 15, 342-356. https://doi.org/10.1130/ges01651.1

Williams, S.A., Singleton, J.S., Prior, M.G., Mavor, S.P., Cross, G.E., Stockli, D.F., 2020, The early Palaeogene transition from thin-skinned to thick-skinned shortening in the Potosí uplift, Sierra Madre Oriental, northeastern Mexico: International Geology Review,63(2), 233-263. https:// doi.org/10.1080/00206814.2020.1805802

Wilson, J.L., 1990, Basement structural controls on Mesozoic carbonates facies in northeastern Mexico: A review:
International Association of Sedimentologists, Special Publication, 9, 235-255. https://doi. org/10.1002/9781444303834.ch9

Whyte, R.J., 1971, Geology and palaeogeography of Chibuluma West orebody, Zambian Copperbelt. Part I. Geology of Chibuluma West: Economic Geology, 66(3), 400-409. https://doi.org/10.2113/gsecongeo.66.3.400

Yang, J., Large, R.R., Bull, S.W., 2004, Factors controlling free thermal convection in faults in sedimentary basins: implications for the formation of zinc-lead mineral deposits: Geofluids, 4, 237-247. https://doi. org/10.1111/j.1468-8123.2004.00084.x

Zhang, Y., Sorjonen-Ward, P., Ord, A., 2006, Fluid flow during deformation associated with structural closure of the Isa superbasin at $1575 \mathrm{Ma}$ in the central and northern Lawn Hill platform, northern Australia: Economic Geology, 101(6), 1293-1312. https://doi. org/10.2113/gsecongeo.101.6.1293 